\title{
The earthenware pottery from the North Moluccan excavations
}

\author{
Peter Bellwood
}

The earthenware pottery from the North Moluccan excavations can be arranged into three easily recognisable chronological groups that can be briefly summarised as follows:

1. Neolithic red-slipped pottery: The oldest pottery recovered is a red-slipped (but otherwise undecorated) and mainly coral sand-tempered ware, represented in the research area only in the bottom two layers (C and D) of Uattamdi 1 rockshelter, Kayoa Island. This red-slipped pottery dates at Uattamdi between outer limits of c. 3350 and 2500 cal. BP (Chapter 5). It is paralleled in the mainly red-slipped but otherwise undecorated pottery excavated in contemporary and older Neolithic sites in the Talaud Islands, northern and western Sulawesi, Sabah in East Malaysia, and much further afield in the Batanes Islands and Cagayan Valley in the northern Philippines, as well as in southeastern Taiwan (Anggraeni et al. 2014; Bellwood 2011; Bellwood et al. 2011; Bellwood and Dizon 2013; Bellwood 2017:Chapters 7 and 8). The circle-, punctate-, and dentate-stamped motifs that are so characteristic of contemporary Marianas Redware and Lapita pottery (Carson et al. 2013) are so far absent during the Neolithic in the Northern Moluccas.

2. Early Metal Phase incised, impressed, and appliqué pottery: This is a very large and relatively unsorted category that might well occupy the whole of Moluccan later prehistory from the late Neolithic and Early Metal Phases onwards, continuing through the era of ceramic trade ware imports until the arrival of Europeans in the early sixteenth century. Much of the late Neolithic and Early Metal Phase repertoire of decorated pottery in the Northern Moluccas has incised, impressed, appliqué, and occasional red-slipped decoration, often with carinated vessel profiles. Pottery of this type occurs in the upper layers (A and B) in Uattamdi (here with metal and glass beads), in Um Kapat Papo and the Buwawansi late Neolithic site complex on Gebe, in Gua Siti Nafisah and the open site of Gorua (near Tobelo in northeastern Halmahera; Ono, Aziz et al. 2017), and in the Morotai sites, especially Tanjung Pinang and the newly excavated northeastern Morotai burial cave of Aru Manara (Ono et al. 2018). Its overall dates are probably between c. 2500 and 1000 cal. BP. This incised, impressed, and appliqué pottery is widely paralleled in a number of other roughly contemporary Island Southeast Asian Early Metal Phase sites—for example, Leang Buidane in Talaud, Sembiran in Bali, and the 'Kalanay' sites in the Philippines (Bellwood 1981, 2007; Ardika 1991; Calo et al. 2015; Solheim 2002). Sometimes associated with it is a rare vessel form with a corrugated rim, reported from Tanjung Pinang on Morotai, similar to the c. 2000-1500 BP 'corrugated ware' at Sembiran in Bali and the Anaro/Mitangeb sites in 
Batanes (Bellwood and Dizon 2013:Fig. 6.10). These rims raise questions about interaction during an early phase of the spice trade, involving in the case of Sembiran a degree of early contact with India (Ardika and Bellwood 1991; Calo et al. 2015, and see below).

3. Pottery of the Asian ceramic trade and European eras (post-1000 BP): In our 1990s fieldwork, we also recovered quite a lot of coarse unslipped pottery, sometimes with appliqué decoration and modelling, in association with imported glazed ceramics, as in Sabatai Tua and the Tanjung Tulang rockshelters on Morotai. Also, overlapping in date with European contact (after 1512), we have the European-influenced pottery from the site of Bukit Keramat on Waidoba Island. Ethnographically and continuing today, a thick-walled handmade red-slipped and pattern-burnished ware is made exclusively on Mare Island and traded from there all over the Northern Moluccas (Mahirta 1996, 2000).

\section{The Neolithic red-slipped pottery from Uattamdi Layers C and D}

This pottery assemblage was perhaps the most significant to be discovered in the Northern Moluccas from the viewpoint of cultural history and Austronesian linguistic dispersal during the late second millennium BCE. It formed part of an introduced complex of material culture with very widespread affiliations in Island Southeast Asia and the western Pacific. This complex, as understood in the Philippines, Sabah, Sulawesi, the Talaud Islands, the Mariana Islands, and the Lapita sites of Island Melanesia and western Polynesia, included red-slipped pottery, either slipped only (as in Talaud, the Moluccas, and southeastern Indonesia generally) or additionally decorated with incised or stamped designs (as in parts of the Philippines, the Marianas, and Oceanic Lapita). It also included polished stone adzes and chisels, shell ornaments and tools, and (in some regions) domestic pigs and dogs.

This plain red-slipped style of pottery-with occasional incision or lip notching, but so far, no circle, dentate, or punctate body stamping - is the oldest style of pottery found in the Northern Moluccas. Indeed, it is the rarity of vessel body decoration other than a simple red slip, both in the Northern Moluccas and in the Talaud Islands, that gives a rather distinctive appearance to southeast Indonesian Neolithic pottery and distinguishes it very sharply from the intricately decorated Lapita Neolithic pottery that occurs to the east of the Papua New Guinea border. This type of plain red-slipped pottery is confined (so far) within the North Moluccan region to Uattamdi alone, and there is no contemporary pottery assemblage from any other site. The closest other occurrences are in the Talaud Islands, especially the rockshelter of Leang Tuwo Mane'e on Karakelong Island, about $500 \mathrm{~km}$ north of Kayoa (Bellwood 1981, 2017:278-279; Tanudirjo 2001), and in the Banda Islands, where Lape et al. (2018) report similar red-slipped plainware from a site on Pulau Ay. No similar Neolithic assemblage is yet reported from southeastern Indonesia, including the Aru Islands (O'Connor et al. 2005:311), although Glover (1986) reported plain and apparently mostly unslipped pottery from cave deposits in Timor Leste.

The Layer C-D assemblage from Uattamdi forms a fairly homogenous collection of red-slipped rims and body sherds, broken and dispersed into the shelter floor at a time when it was used for habitation purposes. The vertical distribution of pottery by sherd weight (Fig. 5.7, bottom) shows a very definite bell-curve, with a peak in spit C4. Although evidence of human occupation in the form of hearths goes down into Layer D, it is quite possible that the bulk of pottery deposition in the site occurred after this hearth phase, at a time when much of the excavated area was becoming piled up with limestone rubble. Absolute dating precision is not possible, but the $\mathrm{C} 14$ dates from the site and parallels elsewhere suggest an absolute outer date range between 3350 and 2500 cal. BP for Uattamdi Layers C and D, as discussed in Chapter 5. 
The Uattamdi Layer C-D Neolithic assemblage itself shows no signs of any marked change over time, and thus appears to represent a stylistic unity. However, the likelihood of continuous scuffing (but not deep disturbance) of the shelter floor during the occupation must be borne in mind. It is very apparent from sherd matches that, at any one time, the soft dry shelter floor would have capped a disturbance zone about $10 \mathrm{~cm}$ deep. There are no signs of any disturbances of great absolute depth, but it is apparent that, as the shelter floor rose over time, so too a zone of sherd cycling and scuffing rose with it. Hence, it should come as no surprise to learn that, in terms of individual rim pieces of identifiable pots, those vessels that have many matching pieces tend to be distributed through several spits. Thus, four rim sherds of the notched-lip vessel illustrated as Figure 7.1(k) occurred in spits C1, C3, C5, and C6 respectively (including one each from $\mathrm{C} 1$ and $\mathrm{C} 6$ that actually fitted together). A possible 20 rim sherds of the red-slipped open bowl shown in Figure 7.1(g) occurred variously in Layers C3 to C6. The sherds of the pedestal vessel shown in Figure 7.1(I) had the same distribution. For this reason, it is safest to regard the assemblage from Layers $\mathrm{C}$ and $\mathrm{D}$ as basically a single assemblage, probably laid down over quite a short time period centred on the deposition of spit C4.

The jar burial assemblage from Layers A and B is quite separate from the older assemblage of Layers $\mathrm{C}$ and $\mathrm{D}$, and there is almost no overlap of cultural materials, apart from a few tiny glass beads that have worked down into Layer $\mathrm{C}$ from above. As discussed in Chapter 5, Layer B is mainly clean beach sand that appears to represent deposition by a tsunami, an event that may well have led to a pause in occupation of the site. This younger Early Metal Phase assemblage is considered separately below.

Some of the basic characteristics of the Uattamdi Layers C and D Neolithic red-slipped assemblage are as follows:

1. Tripod/tetrapod feet, body carinations, spouts, and narrow vertical flask necks are absent in this assemblage, as (not surprisingly, perhaps) are Indian-inspired forms such as kendi spouts.

2. Pedestals are definitely present (Fig. 7.1(I)) on some of the unrestricted vessels with direct rims (i.e. the 'dish-on-stand' type), and there is a single-pedestal sherd with roughly cut-out decoration (not illustrated).

3. Body sherds indicate that most restricted vessels had roughly globular rather than carinated body shapes.

4. Vessel bodies are relatively thin, with a mode between 3 and $4 \mathrm{~mm}$ in all Layers $\mathrm{C}$ and $\mathrm{D}$ spits.

5. Vessel surface decoration is restricted almost entirely to red slip, and notching or scalloping of lips. Vessel (u) in Figure 7.1 has simple curvilinear incision, but this comes from spit C1 and thus may be of later date than the rest of the Layer $\mathrm{C}-\mathrm{D}$ assemblage. The red slip seems to have been brushed on with a wad of some kind, rather than by dipping. This is apparent because of streakiness and differential slip preservation on sherd walls, the latter probably reflecting varying paint thicknesses, and also occasional painted lines. In this regard, the Uattamdi slip resembles that of Leang Tuwo Mane'e on Karakelong Island, Talaud, where red bands of paint can also occasionally be observed (Fig. 7.2).

Of the 33 Uattamdi Layer C-D reconstructable rims shown in Figure 7.1, 21 have coral sand temper and 12 have mineral (presumably volcanic) sand temper. When plotted through time, the coral and mineral sand tempers have similar distributions, although only the mineral sand temper continues into the post-Neolithic Layers A and B. Geological sourcing studies have not been carried out on the Uattamdi pottery, but some preliminary SEM analysis has been carried out on tempers by Mahirta (1996). 


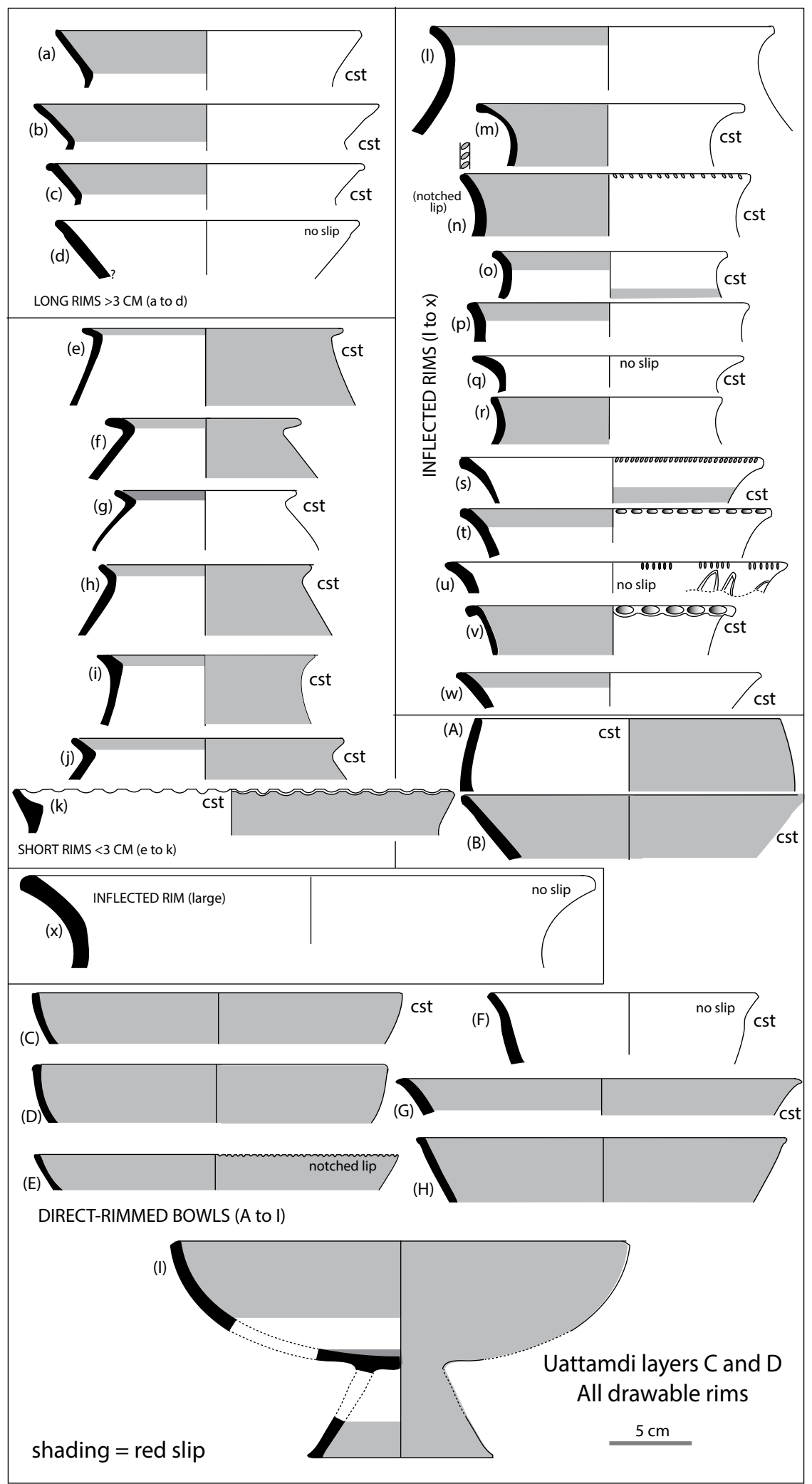

Figure 7.1 Rim sherds from Uattamdi 1 Layers C1 to D2.

cst = calcareous sand temper (others are mineral sand).

Shading = red slip (both internal and external). Unshaded vessels are not slipped.

Source: Peter Bellwood. 
Table 7.1 shows the distribution of red-slipped sherds in the Uattamdi site. Clearly, percentages are highest in Layers $\mathrm{C}$ and $\mathrm{D}$ and peak noticeably around spit $\mathrm{C} 4$, although red-slipped sherds are found in all layers. However, some of the red-slipped sherds in Layers A and B could have been disturbed upwards from below. Table 7.2 shows the vertical distribution of rim forms and attributes through the stratigraphy, but does not include the vessels from Layers A and B that were associated with Early Metal Phase jar burials.

Three additional points about this assemblage can also be noted:

1. Two major whole vessel types are present in terms of basic forms; restricted vessels with everted rims (i.e. 'cooking pot' shapes), and direct-rimmed bowls with unrestricted profiles set on pedestals. Vessel profiles below the neck appear to be gently rounded rather than sharply angled, and there are no carinations in this assemblage.

2. Everted rims of restricted vessels reveal three variants, illustrated as long, short, and inflected in Figure 7.1. The first two variants originate from quite sharply angled eversions and the rims tend to be straight. Long rims and short rims are defined as greater and smaller than $3 \mathrm{~cm}$ in height/length respectively, using a simple and useful statistic originating from the analysis of Batanes pottery (Bellwood and Dizon 2013) that will be discussed further below. The third variant has a non-angular and gently inflected rim eversion attached as a continuous outwards curve. In all three variants, lips are rounded rather than squared-off. Only two of the vessels shown lack red slip altogether, and only one is incised. Rim 7.1 $(\mathrm{k})$ is a unique crenelated lip with an inner recess, apparently shaped to take a lid. One distinctive characteristic of all Uattamdi everted rims is that there is usually a band of red slip extending down over the inner edge of the rim. External surfaces are often red-slipped, but not always.

3. The direct rim bowls shown in Figures 7.1(A)-(I) are mostly unrestricted, except for vessel (A), which is restricted. (B) might also be a long everted rim rather than a bowl rim. These rims tend to be slipped both inside and out, a circumstance that might reflect their usage for food serving. Several of these vessels probably once had pedestals. Lips may be either squared off or rounded. Vessel 7.1(F) has a slightly inflected contour.

Table 7.1 Total sherd and red-slipped sherd distributions by spit and Layer in Uattamdi 1.

\begin{tabular}{|c|c|c|c|c|c|}
\hline $\begin{array}{l}\text { Excavation rows C and E only } \\
\text { (not D), all spits from A to D4 }\end{array}$ & $\begin{array}{l}\text { Total sherds } \\
\text { per spit (no.) }\end{array}$ & $\begin{array}{l}\text { Total sherds } \\
\text { per spit as } \\
\text { a percentage } \\
\text { of all sherds } \\
\end{array}$ & $\begin{array}{l}\text { Red-slipped } \\
\text { sherds per } \\
\text { spit (no.) }\end{array}$ & $\begin{array}{l}\text { Red-slipped sherds } \\
\text { per spit as a } \\
\text { percentage of all } \\
\text { red-slipped sherds }\end{array}$ & $\begin{array}{l}\text { Red-slipped } \\
\text { sherds per spit } \\
\text { as a percentage } \\
\text { of total sherds }\end{array}$ \\
\hline A (all spits) & 439 & 7 & 57 & 3 & 13 \\
\hline B1 & 174 & 3 & 25 & 1 & 14 \\
\hline B2 & 103 & 2 & 20 & 1 & 19 \\
\hline B3 & 118 & 2 & 23 & 1 & 19 \\
\hline B4 & 229 & 4 & 74 & 4 & 32 \\
\hline $\mathrm{C} 1$ & 239 & 4 & 83 & 5 & 35 \\
\hline$C 2$ & 678 & 11 & 161 & 10 & 24 \\
\hline C3 & 741 & 12 & 214 & 13 & 29 \\
\hline C4 & 1070 & 18 & 351 & 21 & 33 \\
\hline$C 5$ & 653 & 11 & 220 & 13 & 34 \\
\hline C6 & 558 & 9 & 184 & 11 & 33 \\
\hline C7 & 269 & 5 & 124 & 7 & 46 \\
\hline D1 & 280 & 5 & 74 & 4 & 26 \\
\hline $\mathrm{D} 2$ & 179 & 3 & 36 & 2 & 20 \\
\hline D3 & 182 & 3 & 38 & 2 & 21 \\
\hline
\end{tabular}




\begin{tabular}{|l|r|l|l|l|l|}
\hline $\begin{array}{l}\text { Excavation rows C and E only } \\
\text { (not D), all spits from A to D4 }\end{array}$ & $\begin{array}{l}\text { Total sherds } \\
\text { per spit (no.) }\end{array}$ & $\begin{array}{l}\text { Total sherds } \\
\text { per spit as } \\
\text { a percentage } \\
\text { of all sherds }\end{array}$ & $\begin{array}{l}\text { Red-slipped } \\
\text { sherds per } \\
\text { spit (no.) }\end{array}$ & $\begin{array}{l}\text { Red-slipped sherds } \\
\text { per spit as a } \\
\text { percentage of all } \\
\text { red-slipped sherds }\end{array}$ & $\begin{array}{l}\text { Red-slipped } \\
\text { sherds per spit } \\
\text { as a percentage } \\
\text { of total sherds }\end{array}$ \\
\hline D4 & 70 & 1 & 32 & 2 & 46 \\
\hline Totals & 5982 & $100 \%$ & 1716 & $100 \%$ & \\
\hline
\end{tabular}

Figures are for all sherds, including body and rim pieces.

Source: Peter Bellwood.

Table 7.2 Pottery attribute distributions with depth (all squares) in Uattamdi 1 (excluding the jar burial assemblage shown in Figure 7.5).

\begin{tabular}{|c|c|c|c|c|c|c|c|}
\hline & $\begin{array}{l}\text { Long everted } \\
\text { rims, } \\
\text { Fig. 7.1(a)-(d), } \\
\text { and possibly (B) }\end{array}$ & $\begin{array}{l}\text { Short everted } \\
\text { rims, } \\
\text { Fig. 7.1(e)-(k) }\end{array}$ & $\begin{array}{l}\text { Inflected } \\
\text { everted rims, } \\
\text { Fig. 7.1(l)-(w) }\end{array}$ & $\begin{array}{l}\text { Direct rimmed } \\
\text { bowls, } \\
\text { Fig. 7.1(A)-(L) }\end{array}$ & $\begin{array}{l}\text { Ratio of red-slipped } \\
\text { to plain rims (total } \\
\text { no. of rims per } \\
\text { layer in brackets) }\end{array}$ & $\begin{array}{l}\text { Notched } \\
\text { lips } \\
\text { (all rim } \\
\text { sherds) }\end{array}$ & $\begin{array}{l}\text { Scalloped lips } \\
\text { (all rim sherds, } \\
\text { possibly from } \\
\text { one vessel) }\end{array}$ \\
\hline A1 & - & - & - & - & $1: 3(4)$ & - & - \\
\hline$A 2$ & - & - & - & - & $2: 0(2)$ & 1 & - \\
\hline A3 & - & - & - & 1 & 1:0 (1) & - & - \\
\hline A4 & - & - & - & - & $0: 1(1)$ & - & - \\
\hline B1 & - & - & - & - & $0: 3(3)$ & 3 & - \\
\hline B2 & - & - & - & - & $2: 4(6)$ & 4 & - \\
\hline B3 & - & - & - & - & $1: 2(3)$ & 2 & - \\
\hline B4 & - & - & - & - & $4: 3(7)$ & 3 & - \\
\hline C1 & 1 & - & - & 1 & 9:2 (11) & 1 & - \\
\hline $\mathrm{C2}$ & 2 & 1 & 2 & 1 & 12:6 (18) & 3 & 2 \\
\hline $\mathrm{C} 3$ & 1 & 3 & 1 & 4 & $15: 5(20)$ & 3 & 1 \\
\hline C4 & 1 & 3 & 2 & 6 & $41: 13(54)$ & 14 & 1 \\
\hline$C 5$ & - & 4 & 1 & 6 & $22: 4(26)$ & 2 & 2 \\
\hline C6 & - & 3 & 3 & 4 & $22: 6(28)$ & 2 & - \\
\hline$C 7$ & - & 1 & - & 2 & $10: 5(15)$ & - & 1 \\
\hline $\mathrm{D} 1$ & - & 1 & - & 1 & $3: 1(4)$ & - & - \\
\hline $\mathrm{D} 2$ & - & 1 & - & - & 1:0 (1) & - & - \\
\hline D3 & - & - & - & - & (0) & - & - \\
\hline D4 & - & - & 1 & - & $1: 1(2)$ & - & - \\
\hline
\end{tabular}

Source: Peter Bellwood.

\section{Regional comparisons for the Uattamdi Neolithic pottery}

It can now be asked how this early Uattamdi red-slipped pottery compares with contemporary and older Neolithic pottery from other regions of Island Southeast Asia. When the Moluccan project was running during the early and middle 1990s, the only other assemblages of this early red-slipped type were those from Madai Cave and Bukit Tengkorak, both in Sabah (Bellwood 1988, 1989), and Leang Tuwo Mane'e in the Talaud Islands (Bellwood 1981). Since 2005, important assemblages of this type have been published from Chaolaiqiao in southeastern Taiwan and the Cagayan valley on Luzon (Hung 2005, 2008), the Batanes Islands in the northern Philippines (Bellwood and Dizon 2013), and the sites of Minanga Sipakko and Kamassi in the Karama Valley of West Sulawesi (Anggraeni et al. 2014). These sites form a relatively well-dated 
sequence through time, with those in the north, in and close to Taiwan, being a few centuries older than those in Sulawesi and the Moluccas. The red-slipped pottery assemblages from all of these sites underwent a number of loosely in-step chronological changes, between 4200 and $2500 \mathrm{BP}$, which indicate some degree of continuing communication with respect to pottery fashion across the whole archipelago (see Fig. 7.4 below). The distances involved in this network were quite large, $2250 \mathrm{~km}$ from the Batanes Islands to Kayoa, for instance, so these observations might be quite relevant for understanding the establishment of this very important phase of human occupation within the Indo-Malaysian Archipelago.

Currently, an overall chronology for red-slipped but otherwise plain pottery ancestral to the type found in Uattamdi Layers C and D commenced around 4200 BP in southeastern Taiwan, Batanes, and northern Luzon. It appeared a little later to the south, c. 3500 BP in West Sulawesi, and perhaps 3350/3250 BP in the Talaud Islands. A related but clearly distinctive red-slipped tradition dominated by a prolific zonal use of dentate-, punctate-, and circle-stamped decoration characterised the northern and central Philippines, the Mariana Islands, and the Lapita sites of Island Melanesia and western Polynesia, with commencement dates in the Cagayan valley in Luzon focusing around 3800 BP (Bellwood 2017).

During the 1990s, the Uattamdi assemblage was suspected to belong to a 'Greater Lapita' complex, defining a way-station on a suggested migration route from Indonesia, around northern New Guinea, to the Bismarck Archipelago. However, the following two decades of research in the southern Moluccas and Nusa Tenggara Timur have yielded nothing to support this reconstruction, and it is now clear in hindsight that two separate migration routes were involved. One entered western Oceania and the Bismarcks via the Philippines and perhaps western Micronesia and the Admiralty Islands. The other travelled into a cul-de-sac in southeastern Indonesia, including the Moluccas, where the energy behind Austronesian expansion was gradually absorbed into an indigenous Melanesian biological and cultural world.

I elaborate on this hypothesis in the final chapter, but it must be emphasised here that the intricately stamped Philippine, Mariana, and Lapita variants of the red-slipped pottery tradition are not in evidence anywhere in southeastern Indonesia, even though we must allow for some Lapita back-movement from the Bismarcks to northeastern Borneo carrying Talasea obsidian (Bellwood 1989). There are possible parallels with dentate-stamping in Sulawesi (Anggraeni et al. 2014; Ono et al. 2019), but these could represent a separate movement from a common Philippine source region. Wherever the Lapita design system originated, its origin was certainly not in the Moluccas, and indeed it is far more likely to have resulted from direct transmission from the Philippines, possibly via the Mariana Islands (Carson et al. 2013).

I propose now to examine the above sites and regions one by one, commencing with sites closest to Maluku and moving gradually further away towards the Philippines and Taiwan. Given the absence of whole vessels and the rarity of body decoration, apart from red slip and notching around lips, it is necessary to concentrate on rim profiles. The guiding structure for this debate will be derived in part from recent observations of the assemblages from Chaolaiqiao in Taiwan, the Batanes Islands in the northern Philippines, and the Karama Valley in West Sulawesi. The earlier-excavated assemblages from Bukit Tengkorak, Leang Tuwo Mane'e, and Uattamdi can now be seen in clearer regional perspective, as will be shown below in Figure 7.4. 
The relevant sites for discussion here are as follows:

1. The rockshelter of Leang Tuwo Mane'e (LTM), Talaud Islands (Bellwood 1976, 1981; Tanudirjo 2001), with a possible commencement date for Neolithic red-slipped pottery of c. 3500 BP (ANU 10209, marine shell, OxCal 4.2; Tanudirjo 2001:160). The LTM Neolithic pottery is shown in Figure 7.2 and in Tanudirjo (2001:Figure 5.8(a)).

2. Bukit Tengkorak Layer 3 (Early Phase), Sabah (Bellwood and Koon 1989; Bellwood 1989; Chia 2003), with a possible commencement date for Neolithic red-slipped pottery of 3200 BP (OZD 767, charcoal, OxCal 4.2). The Bukit Tengkorak Neolithic pottery is shown in Figure 7.3.

3. Minanga Sipakko and Kamassi, Karama valley, West Sulawesi (Anggraeni 2012; Anggraeni et al. 2014), with a possible commencement date for Neolithic red-slipped pottery of c. 3500 BP.

4. Torongan and Reranum Caves on Itbayat Island, and Sunget on Batan Island, northern Philippines (Bellwood and Dizon 2013), with a possible commencement date for Neolithic red-slipped pottery of c. 4200-4000 BP.

5. Chaolaiqiao, southeastern Taiwan (Hung 2005, 2008), with a possible commencement date for Neolithic red-slipped pottery of 4200 BP, based on two charcoal AMS C14 samples.

As stated, all of the above sites except for those in the Karama Valley are distinguished by a lack of pottery decoration apart from surface red slipping and lip notching, and none reveal any presence of the dentate-, punctate-, and circle-stamped styles of decoration that typified contemporary Cagayan Valley, Mariana, and Lapita sites.

Of these assemblages, the closest relations relevant for Uattamdi were undoubtedly with the Talaud site of Leang Tuwo Mane'e, illustrated here in Figure 7.2. The assemblage from LTM also has a few rims on which the red slip comes over the lip to form a band around the top of the vessel interior, as in Uattamdi. The Uattamdi C-D assemblage also resembles that from LTM and Bukit Tengkorak (Fig. 7.3) in being dominated by unthickened rims and thin-walled globular body shapes. Bukit Tengkorak has a wider range of rim cross-sections than Uattamdi or LTM, but shares with them the simple vessel forms (including ring feet) and high frequency of red slip. The complex rim forms and vessel shapes (especially carinated and narrow-necked forms) and the broad variations in surface decoration (especially horizontally zoned incision), so common in Early Metal Phase assemblages in Sabah and the Northern Moluccas, were either absent in these assemblages or, if present, occur only in rudimentary form. For comparison, some of the richly decorated Early Metal Phase pottery from Talaud and Sabah is illustrated elsewhere (Bellwood 1988, 2007:Figs 9.15 and 9.17, 2017).

Even allowing for the dating uncertainties behind these assemblages (all are small and none can be stated with certainty to be absolutely contemporary with any other), it seems a likely hypothesis that they are closely related in origin, but reflect small degrees of differentiation owing to differences in geographical location and date. It can never be proven that all were made by people who shared a close degree of ethnolinguistic relationship, but the differences between the assemblages are certainly not so great that such would be impossible. Indeed, it is interesting that stylistic change occurs in clearly visible ways through time as well as across space, and this is illustrated by the contents of Figure 7.4. 


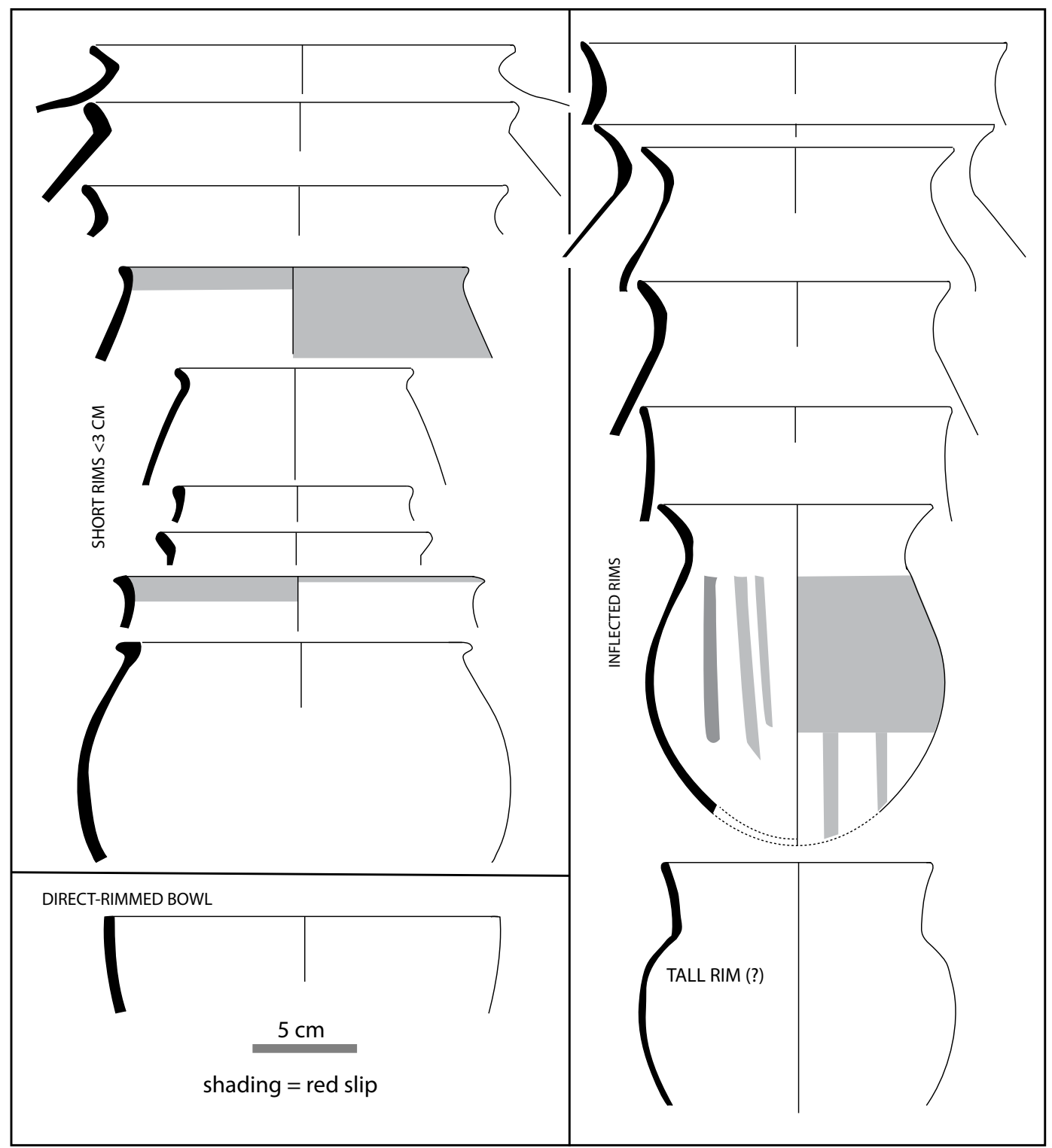

Figure 7.2 Neolithic pottery from Leang Tuwo Mane'e.

Source: Peter Bellwood.

The oldest of these red-slipped but otherwise plainware traditions is currently that from Chaolaiqiao in southeastern Taiwan, where a predominately red-slipped tradition with a very small presence of cord-marked pottery (the latter reflecting descent from the earlier Middle Neolithic fine cord-marked tradition) was excavated by Hsiao-chun Hung in 2005. Chaolaiqiao is quite tightly dated to $4200 \mathrm{BP}$, and is followed in time by the assemblages from the caves of Reranum and Torongan on Itbayat in Batanes, both also dating from about 4200 BP onwards. Following these we have the lower layers of Kamassi and Minanga Sipakko in the Karama Valley of West Sulawesi at c. 3500 BP, and then a group of sites that date roughly between 3500 and 2500 BP. These include Sunget on Batan, Bukit Tengkorak, LTM, Uattamdi, and the upper layers of Kamassi and Minanga Sipakko. 


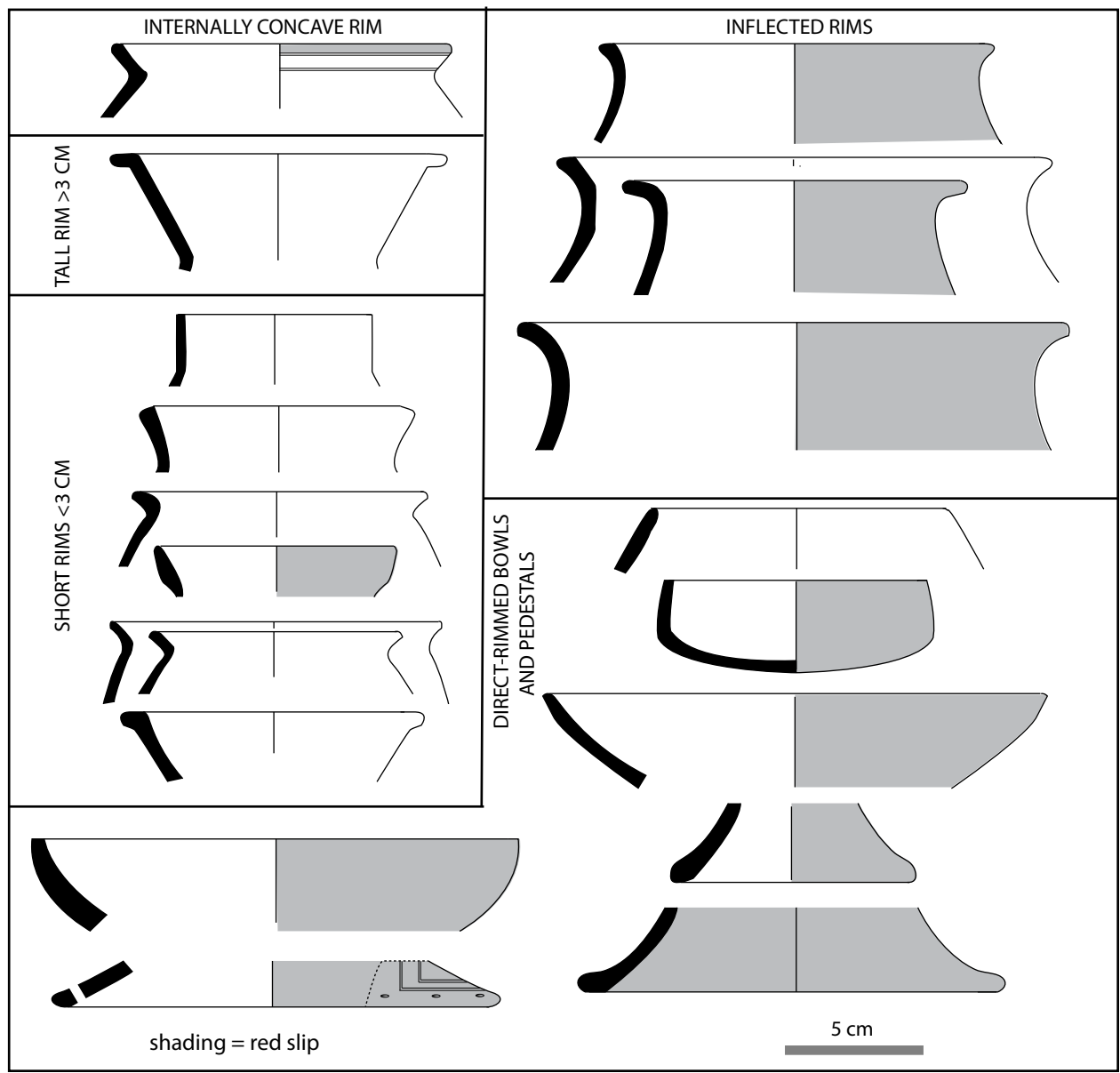

Figure 7.3 Neolithic pottery from Bukit Tengkorak.

Source: Peter Bellwood.

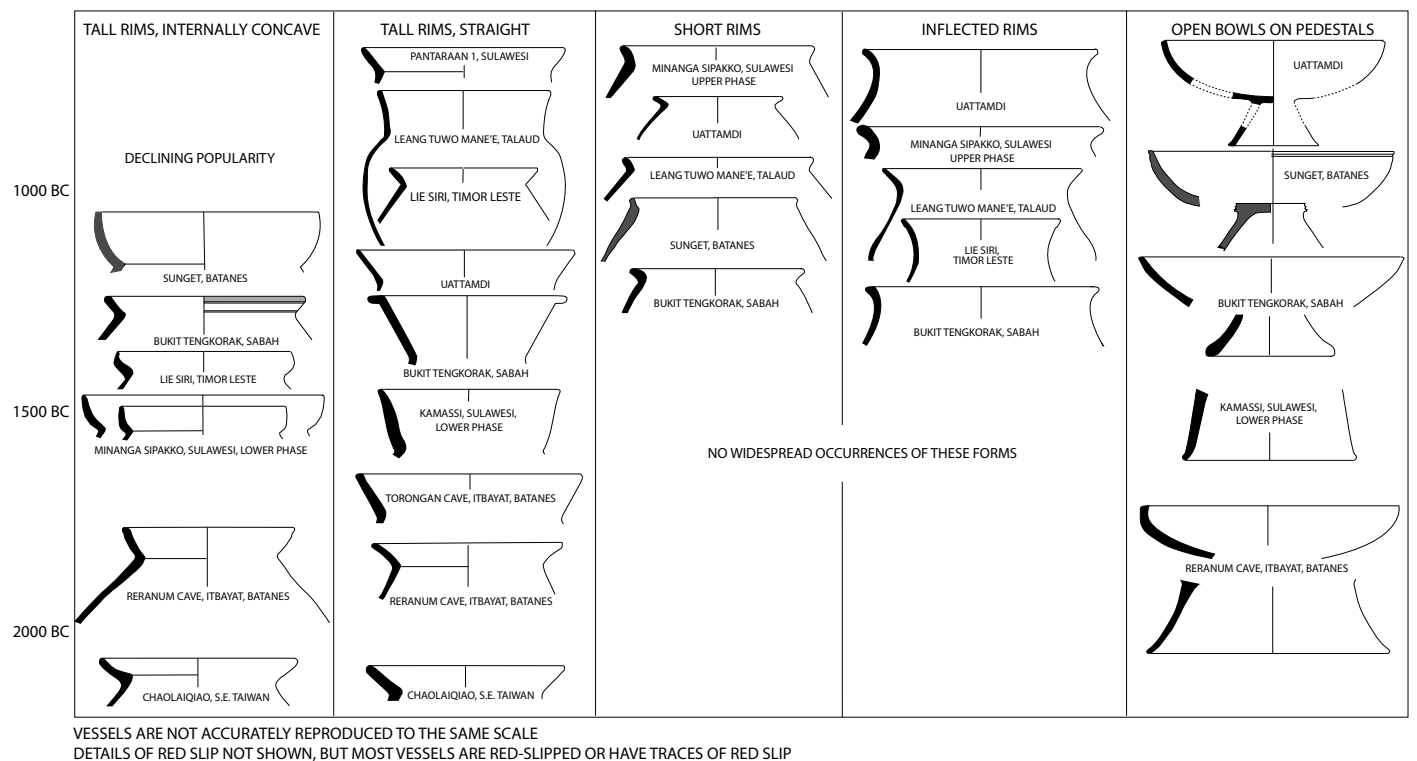

Figure 7.4 A comparison of rim forms from Taiwan to the Moluccas, 4200 to $2500 \mathrm{BP}$ (here shown as 2200 to $500 \mathrm{BC}$ ).

Source: Peter Bellwood. 
Throughout the 1000 years or more of time represented by this site sequence, and across more than $2000 \mathrm{~km}$ of space, it is possible to highlight some trends:

a. The earliest sites have sharply everted rims that are either concave internally or straight, but in both cases generally more than $3 \mathrm{~cm}$ in height/length (Fig. 7.4, the two left-hand columns) (see discussion in Bellwood and Dizon 2013:85). The internally concave rim was particularly important in Chaolaiqiao, Torongan, Reranum, and the early layers of the Karama sites, but was of diminishing importance in Bukit Tengkorak, with only a single specimen. It was absent altogether in eastern Indonesia, and its presence everywhere faded quite rapidly after $3000 \mathrm{BP}$. The long straight rim is found in all regions, but this form also diminished rapidly in frequency after $3000 \mathrm{BP}$.

b. Short rims under $3 \mathrm{~cm}$ in length were becoming dominant by around $3000 \mathrm{BP}$ (Fig. 7.4, middle column), and it was this form that became dominant over the taller forms in the later layers of the Karama Valley sites, and also in Bukit Tengkorak and Leang Tuwo Mane'e. Most rims from Early Metal Age sites in Batanes, and Indonesia generally, tend to be of this short type, often thickened.

c. A gently inflected rather than sharply angled rim form became very popular in Leang Tuwo Mane'e and Uattamdi (Fig. 7.4, fourth column), but this form is not recorded in Chaolaiqiao and Batanes. It seems to have enjoyed its greatest popularity in eastern Indonesia.

d. Red-slipped open bowls with direct rims (Fig. 7.4, fifth column), often on quite high pedestals, occur in all phases from Reranum Cave onwards. This form has antecedents in the Neolithic of the lower Yangzi Valley (as shown in Bellwood 2017:Fig. 8.3).

Admittedly, this sequence spans a large area, a millennium or more of time, and the site components are often small in quantity and affected by chronological uncertainty. Some of the cave assemblages might contain rims that span several centuries of time. But there does seem to be a definite trend here, linking communities from Taiwan to the Moluccas in a gently evolving sequence of vessel rim form associated with red-slipped surface colouring. Both Bukit Tengkorak and the Karama sites have small quantities of stamped pottery, suggesting some degree of contact with the punctate-, dentate-, and circle-stamped pottery tradition that has recently become so significant in the archaeological sequences of northern Luzon, the Mariana Islands, and the Lapita sites of Island Melanesia. The Batanes Islands also witnessed a high popularity of circle stamping after about 3200 BP, as in the site of Sunget on Batan. But Chaolaiqiao, Reranum, Torongan, Leang Tuwo Mane'e, and Uattamdi reveal no trace of this stylistic tradition, which thus appears to have spread slightly later than the initial spread of the red-slipped plainware pottery.

This situation could suggest a scenario that might run as follows:

1. Between 4200 and $3400 \mathrm{BP}$, a tradition of red-slipped but otherwise undecorated pottery spread from southeastern Taiwan, through Batanes, presumably onwards through the Philippines and into Talaud and the Northern Moluccas. This tradition contributed directly to the Neolithic occupation of southeastern Indonesia, but did not spread further east into or beyond New Guinea.

2. After this initial movement, a sub-tradition with a strong focus on stamped decoration developed around $3800 \mathrm{BP}$, possibly initially in the northern Philippines, and spread to the Mariana Islands and Bismarck Archipelago (Carson et al. 2013), and possibly also to northern Sulawesi (Ono, Aziz et al. 2017:118; Ono et al. 2019 for Mansiri). It also spread, with a lesser emphasis on stamped forms of decoration, into eastern Borneo and northern and western Sulawesi (Anggraeni et al. 2014; Chazine and Ferrié 2008; Chia 2003), but evidently not much further. So far, traces of this tradition have not yet been found in Neolithic assemblages in other parts of Indonesia. 


\section{The Early Metal Phase jar burial assemblage from Uattamdi 1, Layers A and B (Early Metal Phase)}

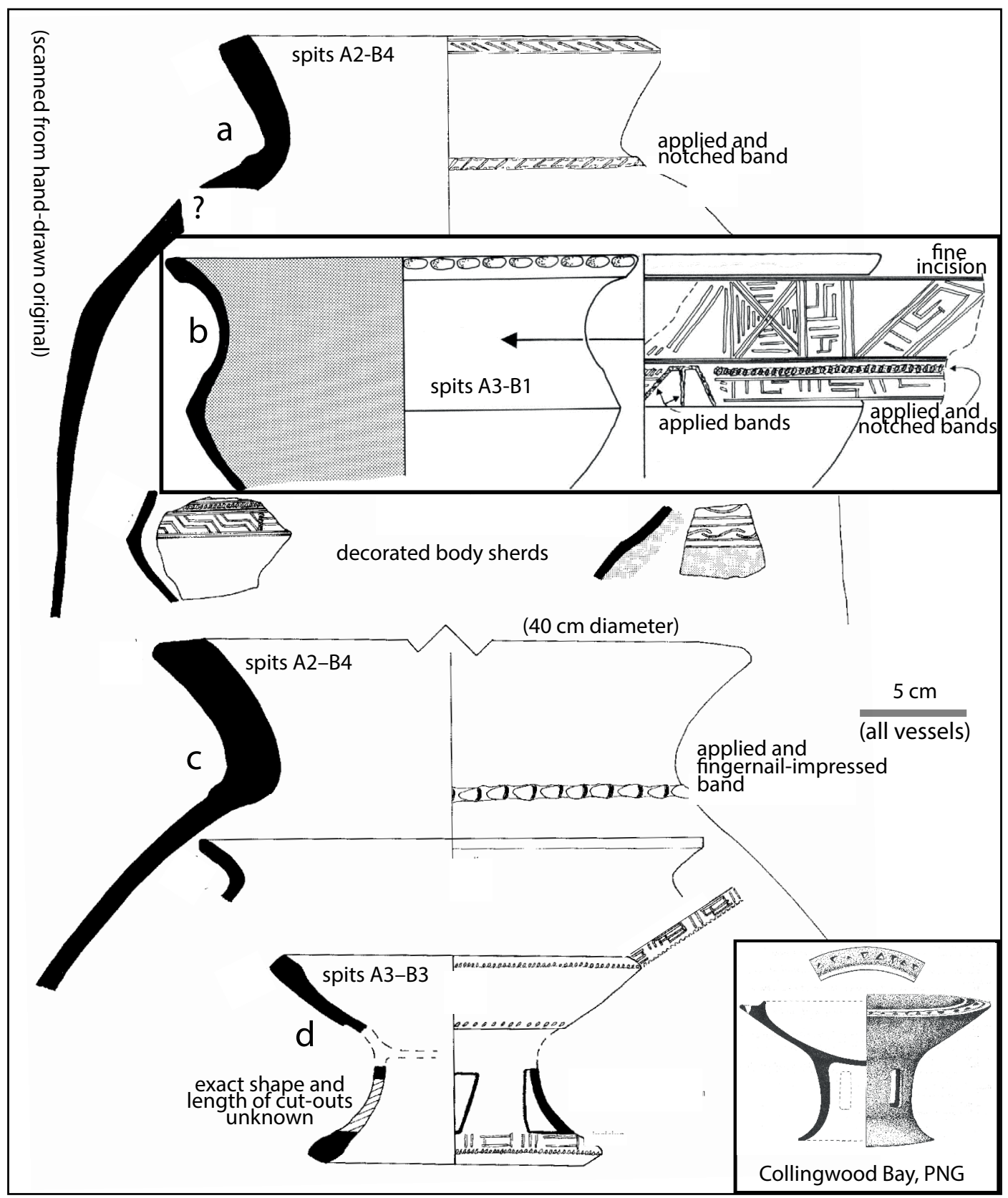

Figure 7.5 Vessels associated with jar burial in Uattamdi 1, Layers A-B (Early Metal Phase).

Shaded zones are red-slipped. The inset vessel $(27.4 \mathrm{~cm}$ in rim diameter) is from Wawa Gardens, Rainu, Collingwood Bay, Papua New Guinea, and is reproduced courtesy of Brian Egloff (1971:Fig. 2). See also Figure 7.10.

Source: Peter Bellwood.

As noted in the Uattamdi excavation report in Chapter 5, the Neolithic assemblage in Layers C and $\mathrm{D}$ is sealed by the clean coral beach sand Layer B. This appears to be the result of a tidal wave, or some other event that caused large quantities of clean beach sand with pumice to be dumped inside the shelter. As shown in the histogram in Figure 5.7 (bottom), pottery sherds occur in small numbers throughout both Layers A and B. Those in the lower B spits seem to 
be an attenuation of the sherd distribution in Layer $C$ beneath, whereas those in the top of $B$ seem to be associated with a burst of jar burial activity in the shelter, with jars presumably partly buried in holes or scoops dug from the top of Layer B, later to be smashed and dispersed into upper Layer B and the overlying Layer A. The distribution of very large body and rim sherds for all Uattamdi excavated squares, of vessels likely to have been used for jar burial purposes, is as follows:

- Spit A2: 3 sherds

- Spit A3: 8 sherds

- Spits A4-A5: 10 sherds (spit A5 did not occur in all squares)

- Spit B1: 9 sherds

- Spit B2: 13 sherds

- Spit B3: 8 sherds

- Spit B4: 3 sherds

- Layers C and D: nil

This distribution indicates that the epicentre of jar burial sherdage is in spit B2, for which there is a marine shell date of 2136-1782 cal. BP (ANU 9322) and a human cranium date of 1932-1813 cal. BP (OxA 35201, see Fig. 11.8). The associations include small quantities of human bone, glass beads, bronze and iron fragments, a shell of a large Turbo marmoratus in direct contact with one small heap of sherds, and sherds of small and highly decorated accessory vessels. The vessels concerned are illustrated in Figure 7.5. The tops of two massive burial jars are shown as Figures 7.5(a) and (c), both with an appliqué neck band either notched or fingertipimpressed. One jar also has lip incision. These jars, and all the other vessels shown for this assemblage, have volcanic sand tempers; the coral sand tempers that dominated Layers C and D are now absent. Although similar burial jars are numerous in the Leang Buidane jar burial cave in Talaud (Bellwood 1976, 1981, 2007:Fig. 9.14), they are of slightly different shapes, and the Talaud sites also have many box-like receptacles, of a type not found at Uattamdi.

Of the small accessory vessels in Uattamdi Layer B, the sharply carinated vessel (Fig. 7.5(b)) with internal red slip and external complex incision and appliqué is most clearly paralleled in Leang Buidane in Talaud (Bellwood 1981) and Agop Atas in Sabah (Bellwood 1988:180, 183; and see illustrations of these vessels in Bellwood 2007:Figs 9.15 and 9.17), with more distant affinities amongst the non-Indian pottery from Sembiran in Bali (Ardika 1991:99) and Bukit Tengkorak in Sabah (Late Phase: Bellwood 1989). This vessel is boxed separately in Figure 7.5 and the decoration is rolled out as though flat for clarity. It has a scalloped rim with small punctuations (not shown) around the top of the lip. The dish on a stand with large pedestal cut-outs (Fig. 7.5(d)) is also paralleled in Sembiran (c. 2000-1500 BP: Ardika 1991:104), and surprisingly in eastern Papua New Guinea (Fig. 7.5(inset)), as discussed further with respect to both Uattamdi and Tanjung Pinang in the final section in this chapter. Pedestals, albeit generally with smaller or no perforations, are common during this period in eastern Indonesia (see Figs 7.10(g) and 7.10(h) for Tanjung Pinang).

All in all, the Uattamdi jar burial assemblage can be seen to have many quite specific parallels with other Early Metal Phase assemblages in Indonesia of the period between 2000 and 1000 BP. Its specific features relate it most closely to assemblages in the earlier part of this time range, closer to 2000 to $1500 \mathrm{BP}$, thus making it possibly slightly older than the Um Kapat Papo assemblage from Gebe, to be described next. 


\section{The pottery from Um Kapat Papo, Gebe Island}

The Um Kapat Papo (UKP) pottery assemblage is small, but of interest because of its relative homogeneity and its association with a marine shell C14 determination of 1765-1437 cal. BP (ANU 9316). This date seems perfectly acceptable, given the nature of this pottery and parallels in other Early Metal Phase sites such as Uattamdi Layers A and B.

The most important point to note about the UKP assemblage is its unity. Although sherds occur from Layer 1 down to a depth of $25-30 \mathrm{~cm}$ from the top of Layer 3, it will be apparent from Table 7.3 that the vast bulk of the sherds are concentrated in Layers 1 and 2, and in the top $10 \mathrm{~cm}$ of Layer 3. There is a marine shell C14 date of 5300-4900 cal. BP (ANU 9317) from $5-15 \mathrm{~cm}$ depth within Layer 3 , and a few sherds do indeed occur at this level, but it would be an insupportable inference that pottery usage in UKP actually dates from this period.

Table 7.3 The distribution of pottery by depth in Um Kapat Papo.

\begin{tabular}{|c|c|c|c|c|c|c|}
\hline Layer and spit & $\begin{array}{l}\text { Glazed ceramic } \\
\text { sherds }\end{array}$ & $\begin{array}{l}\text { Earthenware } \\
\text { sherds, plain } \\
\end{array}$ & \begin{tabular}{|l} 
Earthenware \\
sherds, incised
\end{tabular} & $\begin{array}{l}\text { Earthenware } \\
\text { sherds, red-slipped }\end{array}$ & $\begin{array}{l}\text { Earthenware } \\
\text { sherds, notched lip }\end{array}$ & \begin{tabular}{|l}
$\begin{array}{l}\text { Total } \\
\text { sherds }\end{array}$ \\
\end{tabular} \\
\hline 1 & 2 & 42 & 1 & - & 1 & 46 \\
\hline $2,0-5 \mathrm{~cm}$ & & 88 & 3 & 4 & - & 95 \\
\hline $2,5-10 \mathrm{~cm}$ & 1 & 48 & 2 & 2 & - & 53 \\
\hline $2,10-15 \mathrm{~cm}$ & & 24 & 4 & 1 & - & 29 \\
\hline $2,15-20 \mathrm{~cm}$ & & 32 & 8 & 1 & - & 41 \\
\hline $3,0-5 \mathrm{~cm}$ & & 37 & 1 & - & 2 & 40 \\
\hline $3,5-10 \mathrm{~cm}$ & & 12 & - & - & 1 & 13 \\
\hline $3,10-15 \mathrm{~cm}$ & & 6 & - & - & - & 6 \\
\hline $3,15-20 \mathrm{~cm}$ & & 1 & - & - & - & 1 \\
\hline $3,20-25 \mathrm{~cm}$ & & 3 & - & - & - & 3 \\
\hline $3,25-30 \mathrm{~cm}$ & & 1 & - & - & - & 1 \\
\hline
\end{tabular}

Source: Peter Bellwood.

Figure 7.6 shows two vessels from UKP (those labelled a and c, also listed in Table 7.4) for which large numbers of matching sherds are available. The sherds of both vessels come from several adjacent squares and were found in virtually all of the $5 \mathrm{~cm}$ spits from which pottery was derived. This circumstance, plus the general similarity of all the vessels, suggests that most were placed in the cave over a relatively short period, and that some were then scuffed and disturbed after breakage through the layers where they now occur. The pottery assemblage does not therefore reflect the presence of a stratified sequence.

The tempers and find locations of the sherds of the seven vessels reconstructed in Figures 7.6(a)-(g) are shown in Table 7.4. This list might give the impression that mineral sand tempers are more common in the site than coral sand, but this is not true. A sorting of all sherds after the excavation, including all the unmatched body sherds, indicated that approximately two-thirds of the total contain coral sand. The 5:3 predominance of mineral sands indicated in Table 7.4 thus reflects a bias resulting from the small size of the sample being considered. 
Table 7.4 Tempers and find locations of the sherds of the reconstructed vessels from Um Kapat Papo, labelled as in Figure 7.6.

\begin{tabular}{|c|c|c|c|}
\hline Vessel & Temper & $\begin{array}{l}\text { Location (Square / Layer / } \\
\text { depth in cm within Layer) }\end{array}$ & Number of sherds \\
\hline a & coral sand & $\begin{array}{l}\mathrm{N} 9 / 1 \\
\mathrm{~K} 8, \mathrm{~L} 9,09 / 2 / 0-5 \\
\mathrm{KL} 8, \mathrm{~K} 9 / 2 \text { / 5-10 } \\
\mathrm{L9} / 2 \text { / 10-15 } \\
\mathrm{M9} / 2 \\
\mathrm{M} 9 / 3 \text { / 0-5 } \\
\mathrm{K} 9 / 3 \text { / 5-10 }\end{array}$ & $\begin{array}{l}1 \\
3 \\
2 \\
4 \\
2 \\
1 \\
1\end{array}$ \\
\hline $\mathrm{b}$ & mineral sand, laminated structure & H8 / 3 / top & $\begin{array}{l}\text { unsure-could be } \\
\text { two vessels } \\
\end{array}$ \\
\hline c & coral sand & $\begin{array}{l}\mathrm{K} 8 / 2 \text { / 0-5 } \\
\mathrm{KL} 8 / 2 \text { / 5-10 } \\
\mathrm{L} 9 / 2 \text { / 10-15 } \\
\mathrm{M} 9 / 2 \text { / 15-20 } \\
\mathrm{KL} 8 / 3 \text { / 0-5 } \\
\mathrm{KL} 8 / 3 \text { / 5-15 } \\
\mathrm{KL} 8 / 3 \text { / 15-25 } \\
\end{array}$ & $\begin{array}{l}1 \\
1 \\
1 \\
2 \\
2 \\
1 \\
1\end{array}$ \\
\hline Not illustrated & mineral sand & $\mathrm{L} 9 / 1$ & 1 \\
\hline d & mineral sand & $\mathrm{H} 6-8 / 1$ & 1 \\
\hline e & coral sand & $\mathrm{H} 6-9 / 2 / 0-5$ & 10 \\
\hline$f$ & mineral sand & unstratified & \\
\hline$g$ & mineral sand & H9 / 2 / 0-5 & 2 \\
\hline
\end{tabular}

Source: Peter Bellwood.

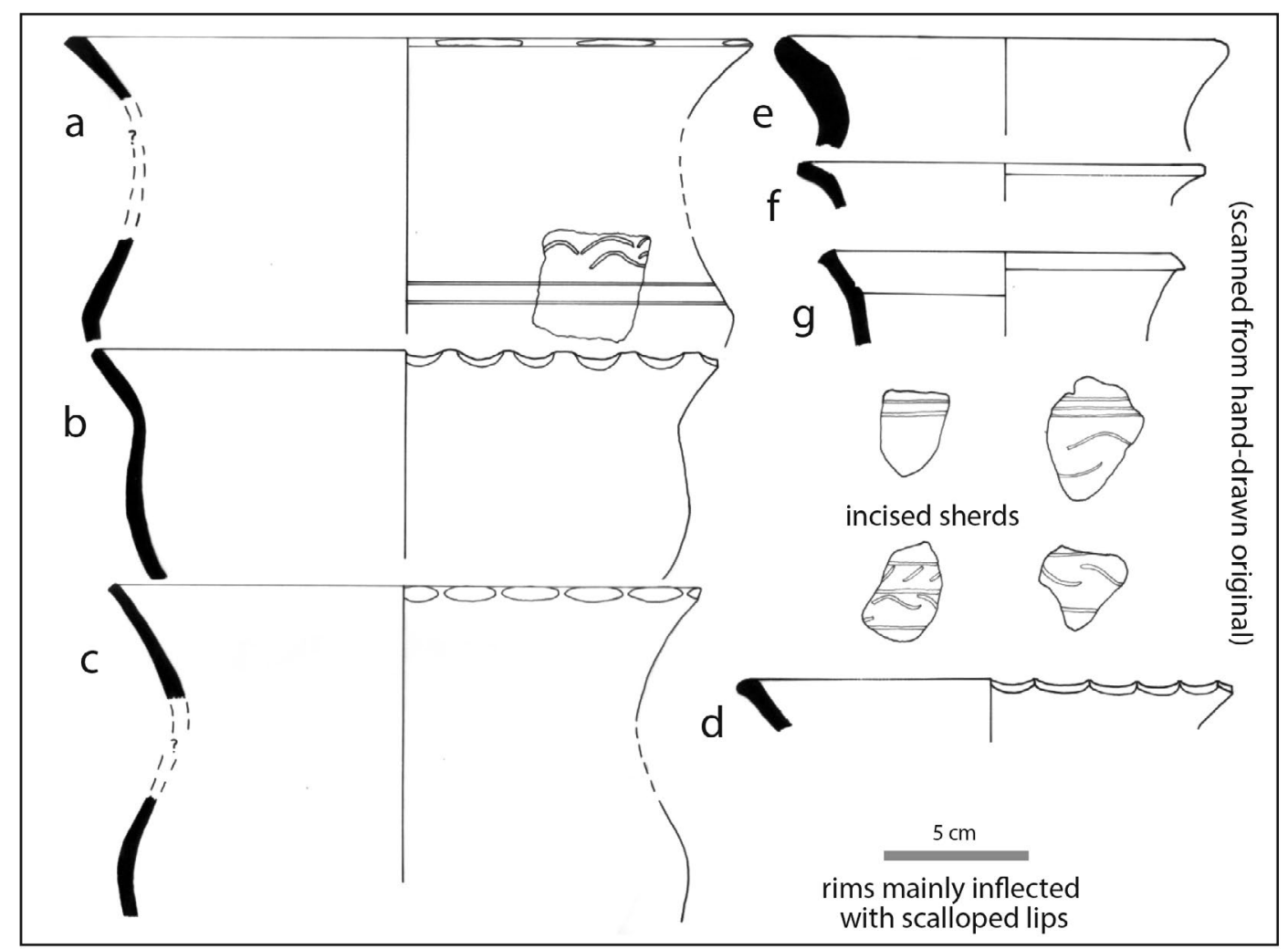

Figure 7.6 Pottery from Um Kapat Papo, Gebe Island, labelled as in Table 7.4. Source: Peter Bellwood. 
The basic design features of the UKP assemblage are simple. The represented vessels are all of restricted forms with everted rims, with long rolled-out lip indentations or scallops being common. In contradistinction to the Neolithic assemblage of Uattamdi Layers C and D, UKP has almost no red slip. Its lip cross-sections are similar to Early Metal Phase types found in Sabah and Talaud (e.g. the Atas phase in Sabah: Bellwood 1988:Chapter 11). It also, like the Early Metal Phase Layers A and B in Uattamdi, and the Early Metal Phase Sabah sites, has carinated body forms (Fig. 7.6(a)). There is also incision in UKP, of a simple curvilinear or parallel straight-line type, contained between parallel horizontal lines, which circumvent the pot. Such incised decoration is similar to that which occurs in the contemporary Moluccan assemblages from Tanjung Pinang and Buwawansi 3 (below), and also from the open site of Gorua (2300 to $2000 \mathrm{BP}$ ) on the northern arm of Halmahera, excavated by Rintaro Ono (Ono, Aziz et al. 2017:Fig. 3).

The UKP assemblage also contains (not illustrated) a fragment of a rim of a square or rectangular vessel (common at this time period in other Early Metal Age sites in Island Southeast Asia), and also a fragment of a flat-based plate on a foot ring (too small to reconstruct). Essentially, it fits comfortably in a time range between 2000 and 1500 BP, approximately contemporary with the pottery assemblages from Uattamdi Layers A and B, Tanjung Pinang, Siti Nafisah and Buwawansi 3. The cave of UKP, a little surprisingly, was obviously not inhabited by the makers of the Neolithic red-slipped pottery of Uattamdi type. No trace of any occupation of this phase has yet been found with certainty on Gebe, although the open site complex of Buwawansi, to be considered next, raises some possibilities.

\section{The pottery from the Buwawansi Site Complex, Gebe}

The Buwawansi pottery sample comes from four major locations, supplemented by surface finds. The four major locations are as follows:

1. The slightly inland rockshelter Buwawansi 1 , which produced a few plain body sherds in the top $30 \mathrm{~cm}$ (Table 2.8).

2. The near-coastal rockshelter Buwawansi 3 (Table 2.9). This site produced the largest assemblage of pottery from Buwawansi (Fig. 7.7).

3. The coastal terrace open sites Buwawansi B5 and B5A.

4. The coastal terrace open site Buwawansi 6 .

All the samples appear to be from one fairly homogeneous pottery tradition, characterised by incised and rare appliqué decoration. The overall time range according to the four available C14 dates with pottery associations is from 3128-1319 cal. BP, according to the calibrated ranges (OxCal 4.2) of the first four marine shell dates for the Buwawansi complex listed in Table 1.1. However, the homogeneity of the pottery and its relations with other dated Early Metal Phase assemblages suggests that a depositional time span of over 1500 years is rather unlikely. The bulk of the pottery probably dates between the 2008-1319 cal. BP time range of C14 samples ANU 9319, 9454, and Waikato 4630.

The 'Neolithic' date of 3128-2789 cal. BP (ANU 9770) from Buwawansi 5 is nevertheless quite intriguing, and raises the possibility that at least some of the pottery on the Buwawansi coastal terrace might be older, even contemporary with that from Uattamdi Layers C and D. This can only be a possibility, and none of the Buwawansi pottery shows any clear resemblance to the red-slipped plainware from the Neolithic layers in Uattamdi. Even the pottery from Buwawansi 5, with the early date of 3128-2789 cal. BP, is incised like that from all the other sites. It seems safest at present to place the Buwawansi assemblage, with those from Um Kapat Papo and Uattamdi C and D, rather firmly in the Early Metal Phase. 


\section{Buwawansi 3}

The largest Buwawansi assemblage, with the best preservation, comes from rockshelter 3 (B3). Here, sherds are distributed to a depth of $60 \mathrm{~cm}$, but with a rapid fall-off below the upper $20 \mathrm{~cm}$ (Table 2.9). The calibrated date of 4271-3811 cal. BP (ANU 9453) from the preceramic base of the site at 130-135 cm adds confidence to the above estimate of a c. 2000-1500 BP date for the pottery, for if the Buwawansi pottery were to have commenced deposition as early as 3000 years ago one would expect sherds to be found to lower levels in this shelter (assuming, of course, that the rate of deposition was fairly regular over time), and there are none.

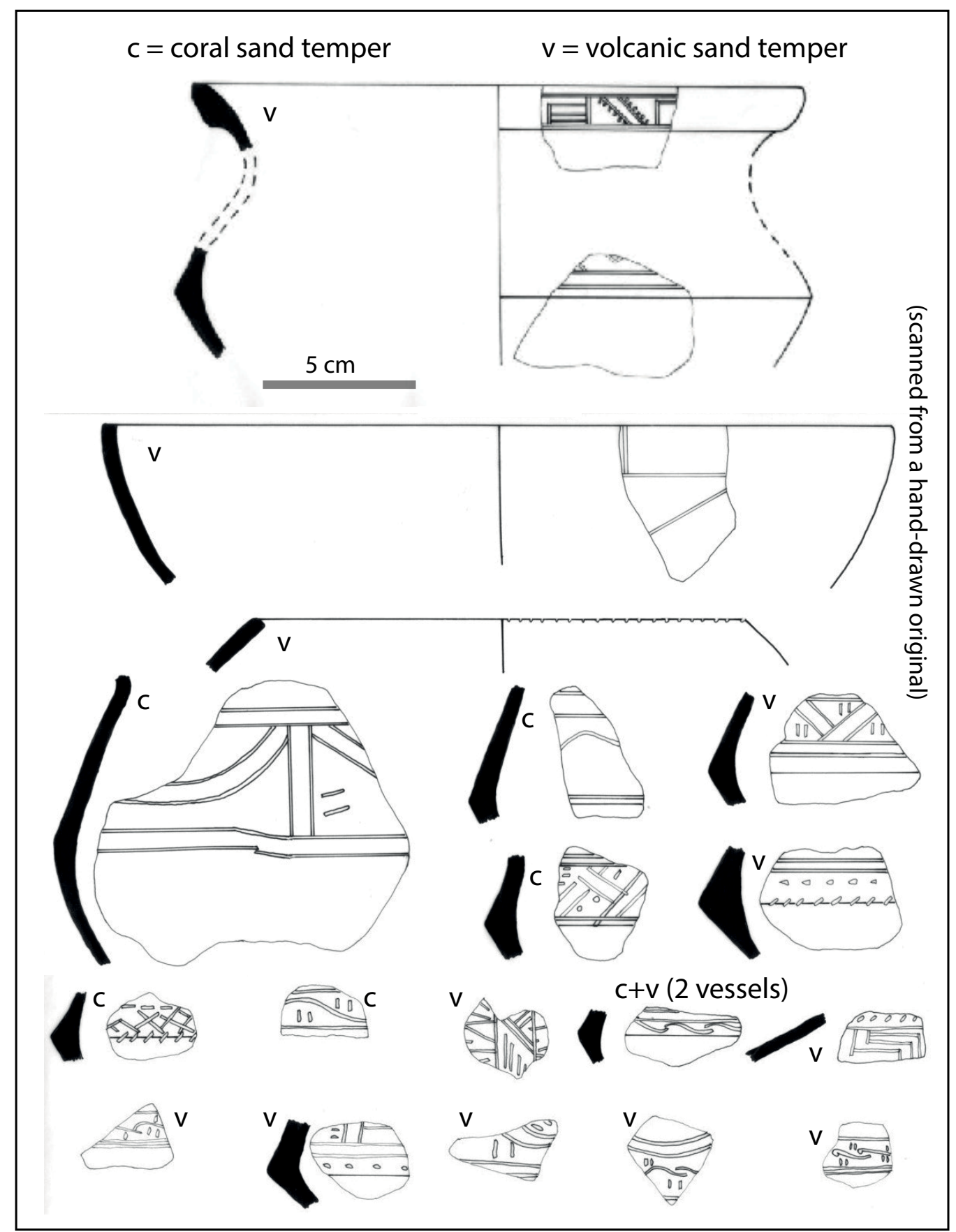

Figure 7.7 Pottery from Buwawansi 3, Gebe Island.

Source: Peter Bellwood. 
Some of the diagnostic sherdage from B3 is shown in Figure 7.7, which also indicates whether tempers are coral sand or volcanic sand. The ratio of coral to volcanic temper, based on the total sample of rim sherds from the site, is $23: 18$. The assemblage is too small to show any significant change over time, and it is treated as a unity for descriptive purposes. The upper small carinated vessel in Figure 7.7 has an identical angular rim form to the Uattamdi vessel in Figure 7.5(c), and this angular cross-section is likewise identical to that of many rims of small carinated vessels from the Agop Atas (Mature Atas phase) and Hagop Bilo sites in Sabah, both dating to approximately c. 2000-1000 BP (Bellwood 1988), and also the rims from the Leang Buidane site in Talaud (Bellwood 1976, 1981).

It can also be seen from Figure 7.7 that sharp carinations are common, that red slipping is relatively rare, and that simple forms of zoned curvilinear and rectilinear incision dominate the decorative repertoire. One rim fragment has a red slip interior band of the type characteristic of the Uattamdi Layers $\mathrm{C}$ and $\mathrm{D}$ assemblage, but apart from this the Buwawansi 3 assemblage has the hallmarks of belonging to the Early Metal Phase. The absence of metal in the site may reflect no more than economic scarcity-Gebe is a very remote island.

\section{Buwawansi 5 and 5A, and Buwawansi 6}

The two roughly oval areas of beach sand marked on Figure 2.20 were test-pitted by four $1 \times 1 \mathrm{~m}$ squares. On the western area, Square B2 produced very little, but B6 was quite rich in pottery distributed down to about $30 \mathrm{~cm}$ depth, with the greatest concentration towards the base. A count of B6 decorated body and rim sherds revealed 85 coral sand tempered sherds, and 35 volcanic sand tempered. Squares B5 and B5A had similar distributions of material.

Basically, the decorated sherds from the Buwawansi 5 and 6 squares are extremely close to those from Buwawansi 3, with horizontal incised zones of simple straight line and curvilinear incision, interspersed with the little trademark 'inverted commas' that appear to be a leitmotif of the Buwawansi and also the Tanjung Pinang assemblages. Similar inverted commas are found on Early Metal Phase pottery from Gorua on Halmahera and Aru Manara on Morotai, as discussed below (Ono, Aziz et al. 2017; Ono, Oktaviana et al. 2017; Ono et al. 2018). A number of these Buwawansi 5 and 6 sherds are drawn in Figure 7.8, together with a number of unusual sherds that merit attention, particularly in terms of unusual rim forms and modelled/appliqué decoration, the latter including the illustrated animal head that appears to have been modelled on to the rim of a small pot.

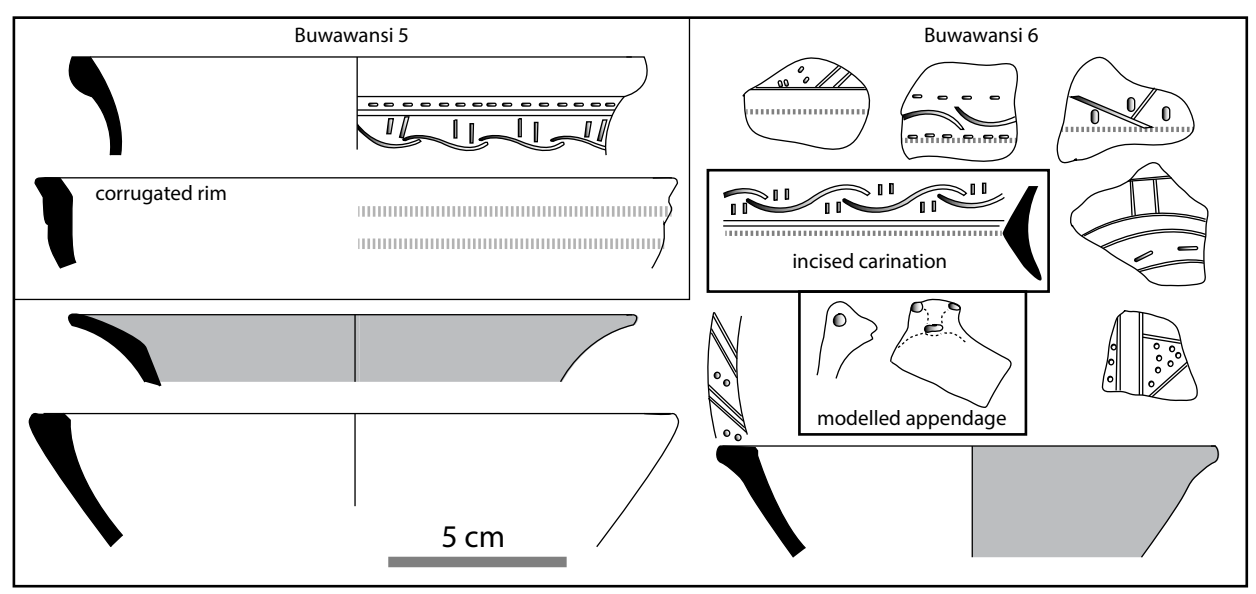

Figure 7.8 Pottery from Buwawansi 5 and 6, Gebe Island.

Shaded zones are red-slipped.

Source: Peter Bellwood.

\section{terra australis 50}


One very important presence in Buwawansi 5 is a single corrugated rim, similar to two specimens of similar date from Tanjung Pinang on Morotai, and many more from sites in the Batanes Islands and Bali, the latter with clear signs of early Indian contact. I return to this issue again below, since the implication is that the Moluccas were brought into westerly trading spheres around 2000 years ago, an observation of no small importance for discussions connected with the origins of the Eurasian spice trade.

\section{A unique sherd from Golo Cave}

The excavations in Golo Cave yielded only 28 small plain body sherds, which do not require further comment. But one large rim sherd of a completely reconstructable vessel was found on the surface of the cave in a small recess at the back. It is illustrated here (Figure 7.9, top), since its incised surface decoration is intricate and skilfully executed. No similar pottery with exactly this type of sloping diagonal decoration was found in any other Moluccan sites, but from the vessel shape and thickened rim we suspect a date in the Early Metal Phase, possibly similar in date to the assemblage from Leang Buidane on Salebabu in the Talaud Islands (Bellwood 1981). The figures in the Leang Buidane report show many similar rims, although the Buidane body decoration differs.

\section{The pottery from Gua Siti Nafisah, Halmahera}

Excavation trench J10 at the back of Gua Siti Nafisah cave produced most of the pottery that was excavated in 1991, associated with a marine shell C14 date of 1628-1598 cal. BP (ANU 7790). Several of the reconstructed vessels in Figure 7.9 had matching sherds from both J10 and from Layer A in the F5-F8 trench, and the assemblage as whole appears to be stylistically unified, perhaps deposited over a relatively short period. Tempers appear to be of volcanic sand.

The Gua Siti Nafisah pottery has a small amount of red-slipped and incised decoration, and in our first report (Bellwood et al. 1993:29) we suggested an affinity with late Lapita pottery in Melanesia. In fact, the Gua Siti Nafisah pottery is perhaps $500-1000$ years younger than the demise of Lapita decoration and, with the benefit of hindsight, this comparison now seems unwarranted. Given the date for J10, this pottery is clearly a regional facies of the North Moluccan Early Metal Phase. It belongs with the contemporary assemblages from Tanjung Pinang and Aru Manara on Morotai, and especially Buwawansi and Um Kapat Papo on Gebe. Gua Siti Nafisah yielded several tiny fragments of notched and scalloped rims like those shown in Figure 7.6 from Um Kapat Papo (all too small for useful illustration), and two body sherds show simple incised patterns between horizontal incised lines that are very similar to specimens from Um Kapat Papo and Buwawansi shown in Figures 7.6 to 7.8.

The Gua Siti Nafisah pottery assemblage appears to be distinctive in its emphasis on the production of direct-rimmed bowls, both restricted and unrestricted, and sometimes carinated in profile. No other North Moluccan assemblage carries this emphasis, and the Uattamdi 1 Layers A and B Metal Phase pottery with its everted rims is more closely related to the Early Metal Phase pottery from other regions to the north and west, such as Talaud and Sabah (Bellwood 1981, 1988, 2017). The Gua Siti Nafisah assemblage therefore has a distinctive local flavour. 


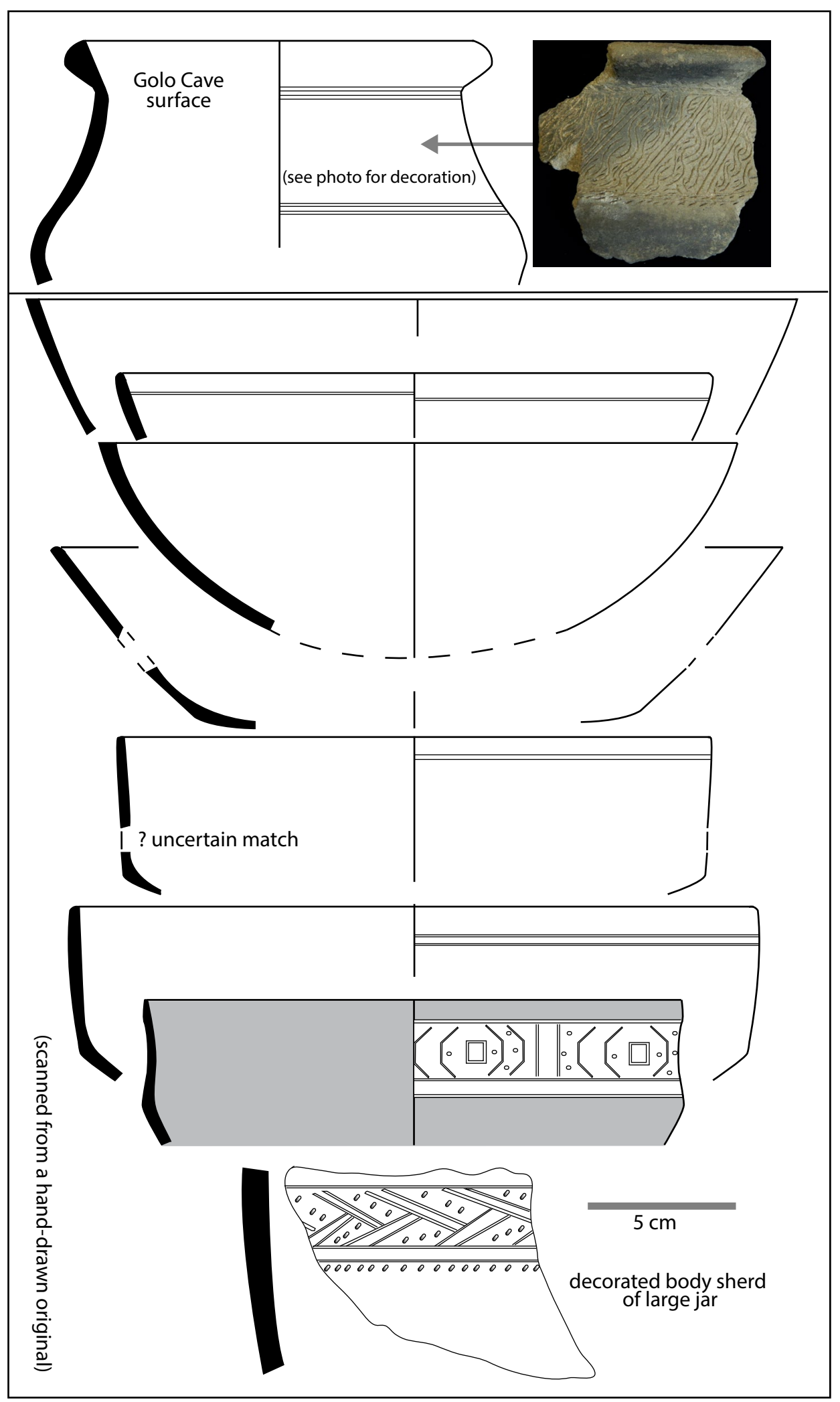

Figure 7.9 Pottery from Golo Cave (Gebe-upper vessel) and Gua Siti Nafisah Cave (eastern Halmahera-lower group).

Shaded zone is red-slipped.

Source: Peter Bellwood. 


\section{The pottery from the Morotai sites}

The pottery excavated in association with the human burials from Tanjung Pinang (see Chapters 3 and 11) reveals a style of incised decoration very similar to that from Um Kapat Papo, Buwawansi, and Gua Siti Nafisah, and to a lesser extent Uattamdi Layers A and B, particularly in its focus on both linear and curvilinear motifs created from paired incised lines (Fig. 7.10, lower left). Unlike Uattamdi, there is no sign of jar burial at Tanjung Pinang, and the pottery seems to have been placed in association with secondary burials, including skulls, placed in shallow pits dug into the shelter floor (Fig. 3.2). As noted in Table 3.1, it was concentrated in the top $25 \mathrm{~cm}$ of the site, and details of vertical distribution by $5 \mathrm{~cm}$ spit are given in Table 7.5. Very little pottery was recovered from the Daeo rockshelters, but Daeo 2 produced a possible corrugated body sherd and the rim of a vessel resembling the dish on stand form from Tanjung Pinang (Figs 7.10(g) and 7.10(h)) discussed below.

Table 7.5 Vertical distribution of selected pottery features in Tanjung Pinang by $5 \mathrm{~cm}$ spit.

\begin{tabular}{|l|r|r|r|r|r|}
\hline Depth cm & Weight gm & Total sherd number & Ribbed bowl rims (number) & \% ribbed & \% incised \\
\hline $0-5$ & 1125 & 360 & 8 & 12 & 2 \\
\hline $5-10$ & 1460 & 375 & 23 & 14 & 7 \\
\hline $10-15$ & 625 & 218 & 11 & 14 & 3 \\
\hline $15-20$ & 361 & 127 & 7 & 20 & 2 \\
\hline $20-25$ & 115 & 36 & 3 & 10 & 10 \\
\hline Totals & 3686 & 1116 & 52 & & \\
\hline
\end{tabular}

Source: Peter Bellwood.

The Tanjung Pinang tempers appear to be the same types of volcanic and coral sand that occur in the other Morotai and Gebe sites, and the general similarities in the predominantly incised decoration are very apparent when the sherds drawn in Figures 7.6 to 7.10 are compared. Tanjung Pinang has similar scalloped lips to Um Kapat Papo, although all these assemblages are rather small, and the parallels could be deemed rather impressionistic. However, the jar burial assemblage from Uattamdi A and B (Fig. 7.5), with its parallels with Leang Buidane in the Talaud Islands (Bellwood 1981), seems to stand a little apart from these other Morotai and Gebe assemblages.

The Tanjung Pinang human bone date of 2684-1618 cal. BP (ANU 8439) matches closely the dates for pottery from Buwawansi and Um Kapat Papo, and emphasises the apparent appearance of pottery-making traditions across the Northern Moluccas beyond Uattamdi in the time interval from c. 2500 to 1600 BP. The new Japanese-Indonesian excavations of the Gorua open site in northern Halmahera and the Aru Manara burial cave in northeastern Morotai by Rintaro Ono and his team (Ono, Aziz et al. 2017; Ono, Oktaviana et al. 2017; Ono et al. 2018) provide much supporting detail for this view. The pottery here was found mixed with secondarily deposited human bones, some cremated, with no clear signs of formal jar burial. Bronze and glass artefacts place the Aru Manara assemblage within the Early Metal Phase, as do the 13 radiocarbon dates from the site, some directly on human bones and teeth. These suggest major burial activity between 2700 and $2000 \mathrm{BP}$, and perhaps later. Gorua is dated by six charcoal C14 dates to 2300 to $1700 \mathrm{BP}$. The Aru Manara pottery has some interesting zoomorphic and anthropomorphic decoration, associated with circle-stamping and punctation, that is not paralleled precisely in any of the sites reported here. However, the Aru Manara pedestalled dish form, and the use of paired incised lines with 'inverted commas' as seen commonly in the pottery from Tanjung Pinang, Gorua, Um Kapat Papo, and Buwawansi, are deserving of comment. The similarities are so precise as to suggest that all of these Halmahera, Morotai, and Gebe pottery assemblages belong to this approximate Early Metal phase time span. 


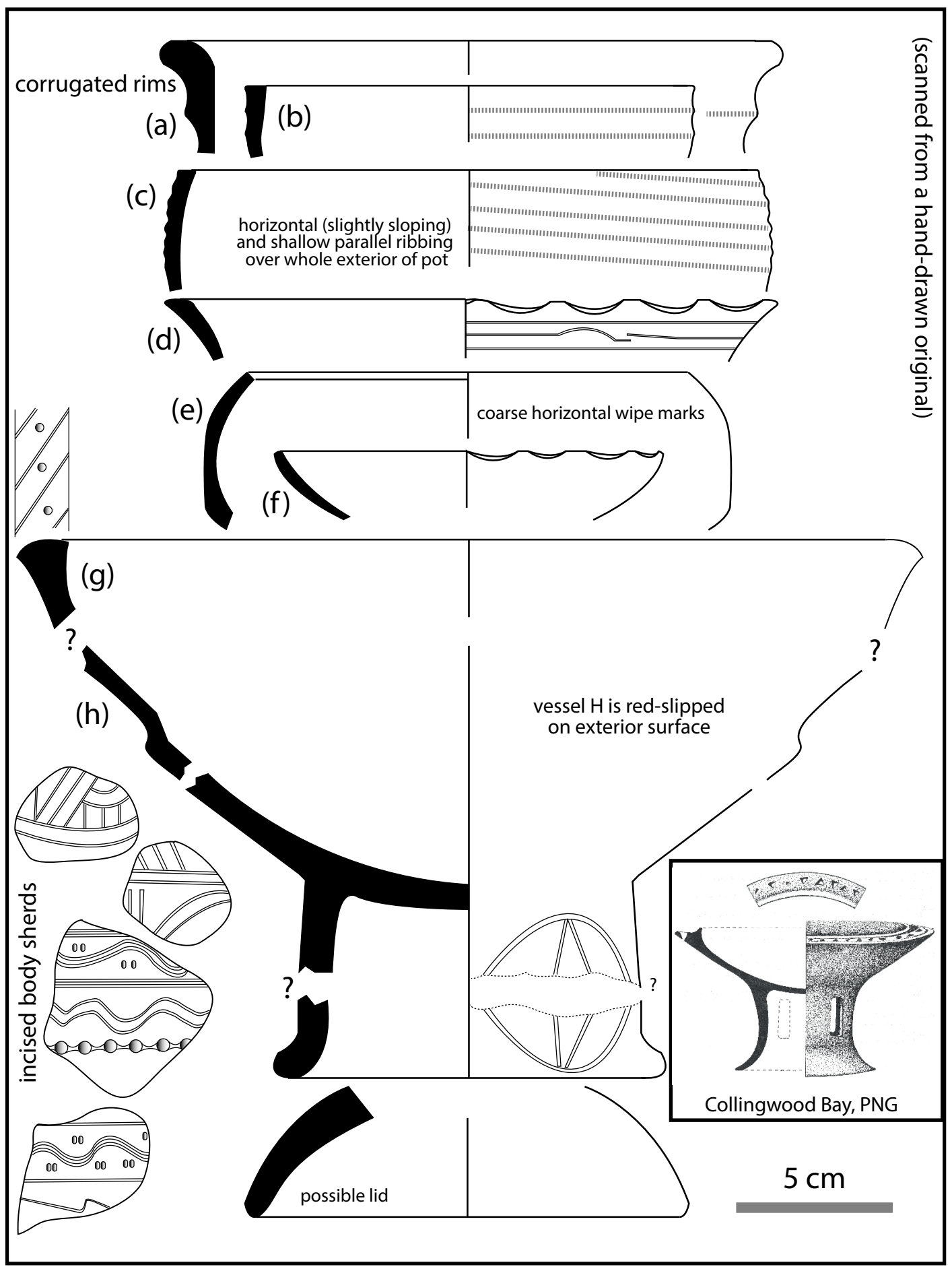

Figure 7.10 Pottery from Tanjong Pinang, Morotai, c. 2000 BP.

The inset vessel (27.4 cm in rim diameter) is from Wawa Gardens, Rainu, Collingwood Bay, Papua New Guinea, and is reproduced courtesy of Brian Egloff (1971:Fig. 2). See also Figure 7.5.

Sources: Peter Bellwood, Brian Egloff, and University of Hawai'i Press.

However, there are also hints that aspects of this kind of incised and applied decoration could have extended later in time, into the period of ceramic import that presumably overlapped in time with the Song and Ming dynasties in China, or early to mid-second millennium CE. These hints come from the sites of Sabatai Tua and Tanjung Tulang, in southeastern Morotai. 


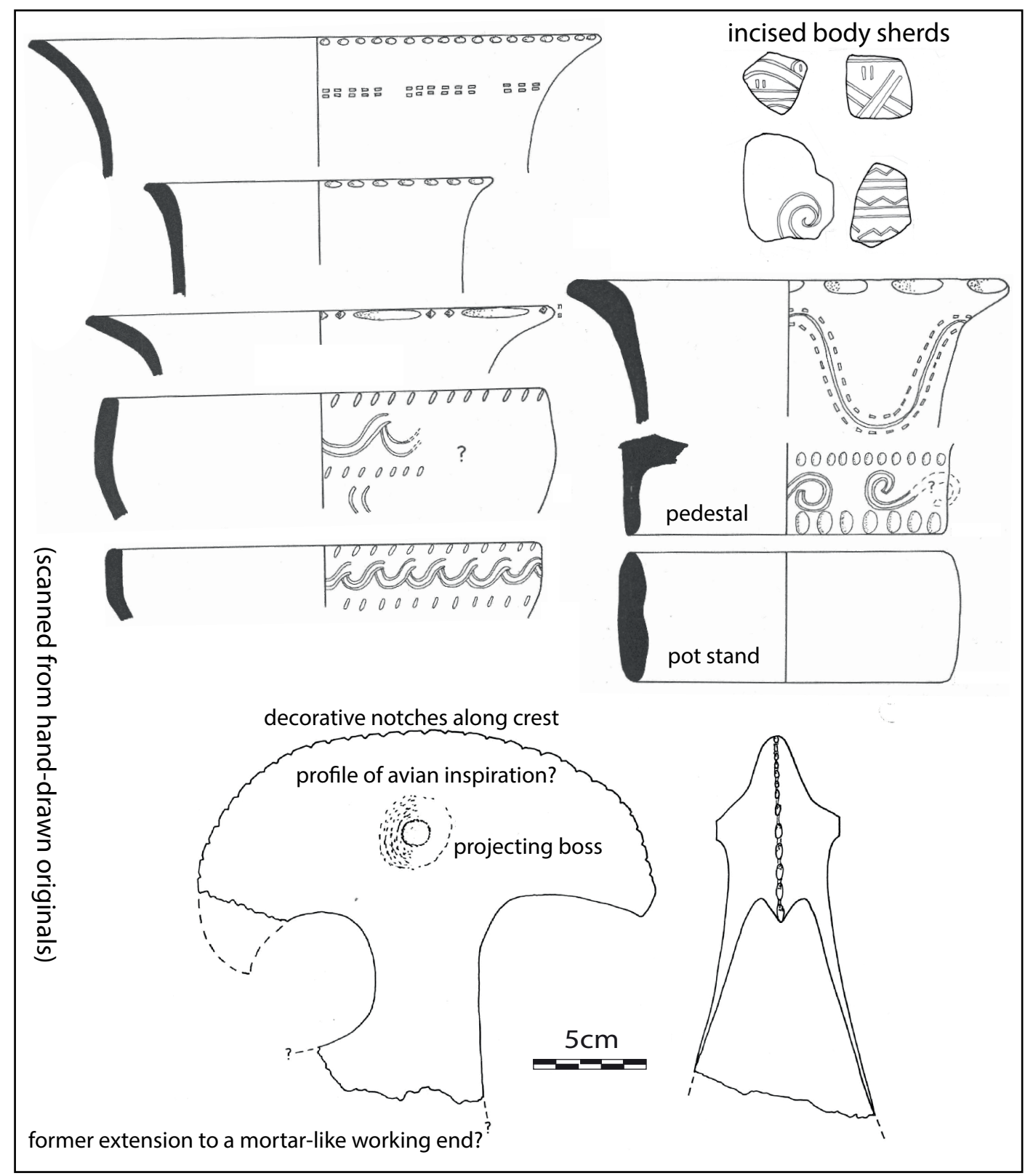

Figure 7.11 Pottery from Sabatai Tua, Morotai.

Source: Peter Bellwood.

Sabatai Tua was an open site on a hilltop, evidently eroded such that the sherds had all come to rest together on top of a thin surface soil. Because a few imported ceramic sherds were found on the site, together with sherds of the ethnographic type of sago mould called a forna (of Portuguese origin), Sabatai Tua was regarded as relatively young when first published in 1993 (Bellwood et al. 1993:28-29). However, some of these sherds of younger appearance could have been intrusive within this mixed surface assemblage. The pottery parallels with earlier sites such as Tanjung Pinang and Ara Manara suggest that Sabatai Tua may hold a mixture of sherds from different periods, some of which might indeed be as much as 2000 years old, or more. 
The assemblage from Sabatai Tua is shown in Figure 7.11, in which it can be seen that the presence of double-line incision and lip scalloping here resembles the assemblages from Buwawansi, Um Kapat Papo, Aru Manara, and Tanjung Pinang. But Sabatai Tua also has many modelled pieces from non-containers, and one, of uncertain function and apparently modelled as a bird's head, is shown also at the base of Figure 7.11. This specimen seems to be unique. Sabatai Tua has also produced several legs and supports of pottery stoves, together with rounded pieces that might be the working ends of pottery pestles, possibly used in food preparation. Similar pieces, not illustrated, were found with imported ceramic sherds in the burial cave of Tanjung Tulang.

\section{Pottery and the Northern Moluccas during the Early Metal Phase}

Apart from the unique and much older red-slipped pottery from Uattamdi on Kayoa, other regions of the Northern Moluccas all reveal their first pottery traditions around 2500 BP. These other regions now include eastern Halmahera (Siti Nafisah), northern Halmahera (Gorua), Gebe (Um Kapat Papo, although Buwawansi might have older ceramic occupation), and now Morotai (Tanjung Pinang, Sabatai Tua, and Aru Manara). As noted in Chapter 6, sherds similar to those from Tanjung Pinang were also collected from the surfaces of two small raised coral islands off southern Morotai, namely Galogalo Besar and Rube Rube. The implication here is that pottery making was initiated at some point after 2700 BP beyond the zone of the older red-slipped pottery in regions that were previously preceramic, spreading across much of the Northern Moluccas. One might wonder why.

A hint about the reason why could come from two observations about these assemblages and their long-distance parallels. The first is that both Tanjung Pinang and Buwawansi 5 have rims with prominent horizontal corrugations that are strikingly similar to those from Mitangeb and Anaro in the Batanes Islands between Taiwan and Luzon, and also from the site of Sembiran on Bali (Bellwood and Dizon 2013:94; Ardika 1991; and see this volume Fig. 7.8, second down on left; Figs 7.10(a) and 7.10(b); and Fig. 7.12). Sembiran has attracted attention in recent years owing to the large quantities of c. 2000 BP Indian Rouletted Ware found there (Ardika and Bellwood 1991; Ardika et al. 1997; Calo et al. 2015). I am tempted to suggest that this distinctive form of corrugated pottery, a form that I have never observed in any preceding Neolithic assemblages in Island Southeast Asia, or in any succeeding post-1500 BP Early Metal Phase ones, is a marker of activity and contact across Island Southeast Asia, involving both Indian stimulus and trade in Taiwan nephrite (Hung 2017:333-335; Hung and Bellwood 2010; Hung et al. 2007) during the centuries around the turn of the Common Era. Of course, the Moluccan Spice Trade comes to mind as one possible reason for all this contact, but this remains surmise. Tanjung Pinang also has many sherds of a direct-rimmed and slightly restricted bowl form, shown in Figures 7.10(b-c), that carry shallow and roughly horizontal surface corrugations on their exteriors. Perhaps these reflect a locally made extension of the same stylistic idea. 


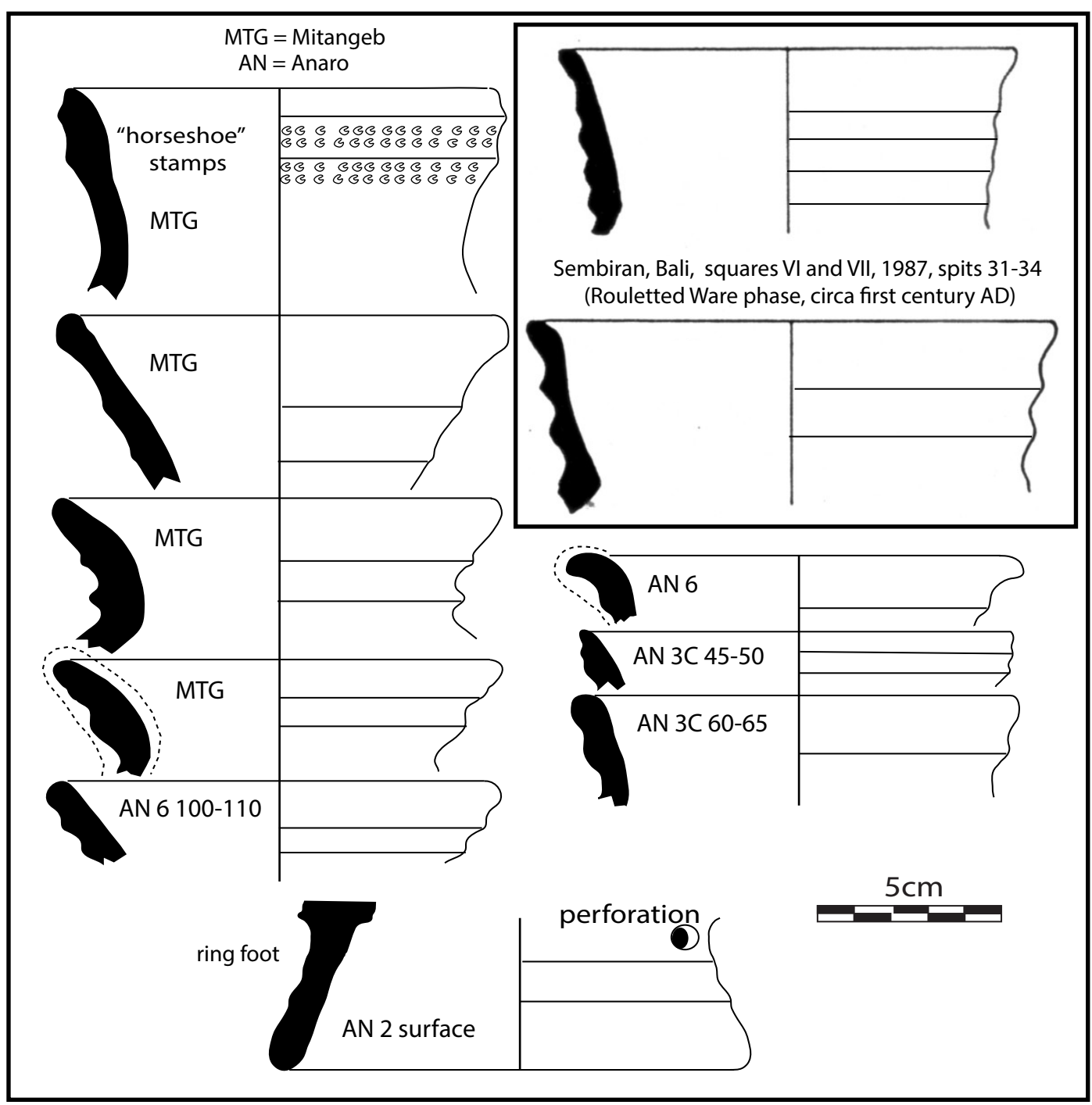

Figure 7.12 Corrugated rims from Mitangeb and Anaro (Batanes), and Sembiran (Bali).

From Bellwood and Dizon 2013, Figure 6.10. The Sembiran sherds are redrawn from Ardika 1991, Figure 5.4. Dotted lines indicate the presence of red slip.

Source: Peter Bellwood.

The second observation about long-distance parallels involves both Uattamdi 1 (Layers A and B) and Tanjung Pinang. Both of these sites have produced open bowls on stands, with cut-outs through the stand in the case of the Uattamdi specimen (Fig. 7.5(d)). Both have broad lips with incised decoration, although in the case of the specimen from Tanjung Pinang it is not absolutely certain that the rim labelled as (g) in Figure 7.10 fits the body labelled (h) (they are similar in fabric). However, similar vessels without pedestal cut-outs occur in Aru Manara (Ono et al. 2018:Figs 3 and 6). Interestingly, there are strong resemblances with a $27 \mathrm{~cm}$ diameter vessel published by Brian Egloff from his investigations in the Collingwood Bay region of eastern Papua New Guinea (Egloff 1971, 1979), and shown inset in both Figures 7.5 and 7.10. The Collingwood Bay vessel is not clearly dated, but in my commentary long ago on this research (Bellwood 1978:266-267) I noted the likelihood of connections between Island Melanesia and Island Southeast Asia in the general Early Metal Phase time period, although at that time the 
most likely connections appeared to be with Solheim's Novaliches complex in the Philippines (Solheim 2002:120), rather than with the Northern Moluccas, which at that time had seen no archaeological investigation.

Now, with the benefit of 40 years of further discovery, we can extend these relationships into the Northern Moluccas, and from the Moluccas back westwards and northwards into other regions of Island Southeast Asia. What has long been termed the 'Early Metal Phase', 'Bronze-Iron Age', or often simply 'Iron Age' in Island Southeast Asian archaeology could turn out to have been a period of remarkable contact and trade-based activity, focused on the centuries around the turn of the Common Era, with repercussions extending as far as India, Island Melanesia, and beyond. The extent of this 'beyond' in a Pacific direction could be marked by very positive similarities in certain types of New Zealand Maori and Iron Age Philippine nephrite artefacts, as discussed by me elsewhere (Bellwood and Hiscock 2018:Fig. 9.22). In my view, these similarities after $2000 \mathrm{BP}$ are too strong to reflect mere chance, and of course far too late in time to reflect Neolithic migration patterns more than a millennium beforehand. But actual group-to-group contact remains just as likely as a more diffuse and so far undemonstrated concept of shared artistic ancestry.

It would perhaps be unwise to push these comparisons too far. But Pacific Island archaeologists in particular should be critical of the idea that distant Oceanic islands, once settled during Lapita times or later, were thereafter beyond the range of any long distance contact with Island Southeast Asia. In fact, I doubt that any modern archaeologist would hold such a view (see, for instance, Addison and Matisoo-Smith (2010) for an argument against it that involves Polynesian origins). The ability of ancient peoples to cross long distances at sea becomes ever more apparent as research proceeds.

In Chapter 13, these suggestions are discussed further, especially with respect to the likely spread of pottery into Papuan-speaking communities on Morotai, Halmahera, and Gebe around 2000 years ago from an earlier Austronesian-influenced node of pottery making activity in the islands west of Halmahera (for instance, Uattamdi). Linguistic evidence for contacts between the Moluccas and eastern Papua New Guinea will also be discussed. The early spice trade again beckons as a potential stimulus for such movements. 
This text is taken from The Spice Islands in Prehistory: Archaeology in the Northern Moluccas, Indonesia, edited by Peter Bellwood, published 2019 by ANU Press, The Australian National University, Canberra, Australia. 